\title{
ZAKONITOST ŠTRAJKA - QUI, QUID, QUANDO ET QUOMODO?
}

Sažetak: U kontekstu globalizacije bilježimo ubrzano kretanje kapitala i usluga izvan nacionalnih granica država članica EU-a, stoga transnacionalne transakcije postaju svakodnevica, kao i izaslani radnici. Budući da poslodavci žele iskoristiti prednosti koje im nudi pojedino unutarnje tržište i time sniziti cijenu rada, spomenuti radnici se nalaze u nezavidnoj poziciji. Stoga je za zaštitu njihovih ekonomskih $i$ socijalnih interesa nužna uspostava produktivnog transnacionalnog socijalnog dijaloga. No, zbog različitosti stupnja gospodarskog razvoja te socijalne zaštite izvjestan je neuspjeh kolektivnih pregovora socijalnih partnera i pokretanje štrajkova, najdjelotvornijih industrijskih akcija na strani svijeta rada. Medutim, kolektivne akcije i dalje su vezane uz nacionalni sustav industrijskih odnosa obilježenih svojim specifičnostima. No, valja naglasiti da $i$ unutar tih sustava postoji niz pravnih praznina ili/i loših rješenja glede regulacije industrijskih akcija, posebice prava na štrajk. Situaciju posebno usložnjava postojanje medunarodnih i regionalnih pravnih izvora koji reguliraju navedenu materiju, a koje obvezuju odnosne države, posebice u situaciji kada odredbe nacionalnog zakonodavstva nisu s istima usklađene. Stoga nije teško zaključiti da spomenuta situacija otežava, ne samo organiziranje i provedbu štrajka, već i razgraničenje zakonitog od nezakonitog štrajka $i$ to ne samo na transnacionalnoj, već $i$ na nacionalnoj razini. $U$ radu autori, koristeći komparativnu metodu, iznose brojne kritike de lege lata nudeći rješenja de lege ferenda.

Ključne riječi: $\quad$ zakoniti i nezakoniti štrajk, materijalne i procesne pretpostavke zakonitosti štrajka, sudska zabrana štrajka.

* Dr. sc. Andrijana Bilić, izvanredna profesorica na Katedri za radno i socijalno pravo Pravnog fakulteta Sveučilišta u Splitu, Domovinskog rata 8, 21000 Split, Republika Hrvatska. Adresa e-pošte: andrijana.bilic@pravst.hr. ORCID: https://orcid. org/0000-0002-1272-4749.

** Trpimir Perkušić, mag. iur., asistent na Katedri za radno i socijalno pravo Pravnog fakulteta Sveučilišta u Splitu. Domovinskog rata 8, 21000 Split, Republika Hrvatska. Adresa e-pošte: trpimir.perkusic@pravst.hr. ORCID: https://orcid.org/0000-00034561-9926. 


\section{UVOD}

Od samih začetaka radnog prava pa sve do njegove suvremene razvojne faze prisutna je opće prihvaćena paradigma o nejednakosti pregovaračkih pozicija između poslodavca i radnika pojedinca u radnom odnosu na tržištu rada. Stoga se ta neravnoteža nastojala kompenzirati priznavanjem prava radnika na udruživanje i kolektivno pregovaranje. No, navedeno pravo bi za svijet rada bilo samo mrtvo slovo na papiru ako isti ne bi raspolagali efikasnim sredstvom kojim bi poslodavce prinudili da prihvate njihove zahtjeve, odnosno da odustanu od svojih u situaciji kada njihovi međusobni pregovori zapadnu u tzv. pat-poziciju. Najdjelotvornije sredstvo u tom kontekstu predstavlja štrajk. I u suvremenim uvjetima gospodarskih kretanja u radnom odnosu ${ }^{1}$ u prvi plan izlaze suprotstavljeni zahtjevi poslodavaca (da se prilagode gospodarskim promjenama na tržištu proizvoda/usluga uz što manje troškove rada) i radnika (za sigurnošću zaposlenja, boljim uvjetima rada, većom plaćom i dr.) koji svoje interese nastoje postići kolektivnim pregovaranjem. No, u razdoblju globalne gospodarske krize kolektivno pregovaranje sve manje postiže svoju svrhu pa bilježimo sve češće različite oblike industrijskih akcija, u prvom redu štrajk. No, štrajk, kao jedan od oblika industrijske akcije, trebao bi biti ultima ratio u ostvarivanju tih zahtjeva budući da za vrijeme štrajka mogu biti ugroženi, kako zajednički interesi obiju strana radnog odnosa, tako i trećih, korisnika njihovih proizvoda/ usluga, a štoviše i opći nacionalni (državni) interes. Stoga se treba organizirati i provoditi prema pravilima utvrđenim nacionalnim poretkom.

Zbog navedenog, nacionalni pravni poreci, pa tako i onaj Republike Hrvatske, razgraničava pravom dopušten, organiziran i proveden štrajk od nezakonitog štrajka. No, odgovor na pitanje razgraničenja zakonitog od nezakonitog štrajka ne nalazimo samo u nacionalnoj regulativi, već i u međunarodnoj i regionalnoj te doktrini ${ }^{2}$ i sudskoj praksi. ${ }^{3}$

U okviru međunarodne regulative pravo na sindikalne slobode i pravo na štrajk, kao temeljne slobode i prava čovjeka, zajamčeni su u međunarodnim aktima (ugovorima) o ljudskim

1 Bilić, A., Fleksibilnost i deregulacija u radnopravnim odnosima, doktorska disertacija, Pravni fakultet Sveučilišta u Splitu, Split, 2012., str. 10.: radni odnos se određuje kao "društvenopravni odnos između poslodavca i radnika koji se temelji na njihovom sporazumu (eksplicitnom ili implicitnom, u pisanoj ili usmenoj formi), na temelju kojeg se radnik obvezuje osobno obavljati određeni rad prema uputama i nalozima poslodavca koji mu se zauzvrat obvezuje osigurati potrebna sredstva za rad, strojeve, materijal, alat, uvjete rada te isplatu naknade (plaću) za obavljeni rad, poštujući norme predviđene zakonom, kolektivnim ugovorom i pravilnikom o radu koje reguliraju njihov međusobni odnos."

2 U državama u kojima je pravo na štrajk zajamčeno kao ustavno pravo valja postaviti sljedeća pitanja: je li određena akcija “štrajk" u smislu ustavne odredbe; je li ista zlouporaba ustavom zajamčenog prava te jesu li sve akcije u sklopu te akcije obuhvaćene ustavnom zaštitom (Kahn-Freund, O., The Right to Strike. Its Scope and Limitations, Strasbourg, Council of Europe, 1974., str. 13.; U Francuskoj doktrina razlikuje materijalne (prekid rada i kolektivni karakter akcije) i psihološke (namjera radnika glede štrajka, dogovor o štrajku i profesionalni cilj štrajka) pretpostavke dopuštenosti štrajka. (Javillier, J. C., Manuel de droit du travail, L. G. D. J. Paris 1986., str. 259.-260. U Italiji doktrina zbog Ustavom priznatog prava na štrajk ne razlikuje zakonite od nezakonitih štrajkova te se do odgovora na to pitanje dolazi posredno analizom vanjskih (odraz su sukoba prava na štrajk s nekim drugim Ustavom zajamčenim ljudskim pravom te se odnose na ograničenje štrajka u nužnim javnim službama) i unutarnjih (proizlaze iz sudskog tumačenja prava na štrajk te se odnose na suvremene oblike štrajka, kao što su odbijanje prekovremenog rada, isprekidani i rotirajući štrajkovi i sl.) ograničenja prava na štrajk. (Kyovsky, R., Pravna ureditev stavke, Združeno delo, br. 14, 1988., str. 814. citirano prema: Potočnjak, Ž., Pravo na štrajk, Pravni fakultet u Zagrebu, Savez samostalnih sindikata Hrvatske, Zagreb, 1992., str. 47.-48.)).

3 Primjerice, u Italiji Kasacijski sud u presudi br. 711/1980 u odgovoru na pitanje zakonitosti štrajka razlikuje dvije situacije: uzrokuje li štrajk za poslodavca "štetu proizvodnji" (mogućnost postizanja na određenom stupnju ekonomske aktivnosti određeni rezultat proizvodnje te poslodavca gubi određene prihode u slučaju štrajka) ili "štetu produktivnosti” (ima utjecaj na proizvodni kapacitet tvrtke, odnosno utječe na mogućnost nastavka poslodavčeve vlastite ekonomske inicijative. U prvom slučaju štrajk bi bio zakonit, a u drugom nezakonit. 
pravima. Tako je prema Međunarodnom paktu o ekonomskim, socijalnim i kulturnim pravima čovjeka od 16. prosinca 1966. ${ }^{4}$ obveza država članica osigurati pravo na štrajk (pod uvjetom da se izvršava prema zakonom utvrđenim pretpostavkama određene zemlje). Pravo na industrijske akcije, pa samim tim i na štrajk na međunarodnoj razini, priznato je u dvjema konvencijama Međunarodne organizacije rada, Konvenciji br. 87. o sindikalnim slobodama i zaštiti sindikalnih prava iz $1948 . .^{5}$ kao i Konvenciji br. 98. o pravu na organiziranje i slobodno kolektivno pregovaranje iz 1949. ${ }^{6}$ Međutim, navedene konvencije ne navode izrijekom pravo na štrajk. ${ }^{7}$

U pogledu priznanja prava na štrajk na europskoj razini valja istaknuti Europsku socijalnu povelju iz $1961 .^{8}$ koja od država zahtijeva da priznaju pravo radnika i poslodavaca na kolektivne akcije, uključujući pravo radnika na štrajk. ${ }^{9} \mathrm{U}$ području prava Europske unije Europska konvencija za zaštitu ljudskih prava i temeljnih sloboda i prateći protokoli ${ }^{10}$ jamče slobodu udruživanja, kao i osnivanje sindikata i pristupanje istima radi zaštite interesa radnika. ${ }^{11} \mathrm{Na-}$ dalje, Povelja o temeljnim pravima EU-a iz 2000. godine ${ }^{12}$ u čl. 28. uređuje pravo na kolektivno pregovaranje i industrijske akcije. Međutim, u Ugovoru o EU-u i Ugovoru o funkcioniranju EU-a, osnivačkim ugovorima Zajednice, odnosno Europske unije ${ }^{13}$ pitanje prava na štrajk isključeno je iz nadležnosti tijela EU-a. No, to ne znači da je to pitanje prava na štrajk isključeno iz legislativne kompetencije Unije i iz nadležnosti Suda pravde Europske unije ${ }^{14}$ te Suda za ljudska prava Vijeća Europe. ${ }^{15}$

4 Međunarodni pakt o ekonomskim, socijalnim i kulturnim pravima čovjeka (Službeni list SFRJ, broj 7/1971, Narodne novine, Međunarodni ugovori, broj 12/1993).

5 Konvencija Međunarodne organizacije rada br. 87. o pravu na sindikalno organiziranje (Narodne novine, Međunarodni ugovori, broj 3/2000). Vidjeti šire: Buklijaš, B., Bilić, A., Međunarodno radno pravo, Pravni fakultet Sveučilišta u Splitu, Split, 2006., str. 142.-147.

6 Konvencije Međunarodne organizacije rada br. 98. o pravu na organiziranje i slobodno kolektivno pregovaranje (Narodne novine - Međunarodni ugovori, broj 3/2000). Vidjeti šire: Buklijaš, B., Bilić, A., Međunarodno radno pravo, op. cit. u bilj. 5, str. 147.-150.

7 No, to ne znači da ga Međunarodna organizacija ne priznaje. Naime, Odbor za slobodu udruživanja Međunarodne organizacije rada utvrdio je temeljna načela prava na štrajk koja ujedno predstavljaju granice dopuštenosti prava na štrajk: štrajk se smatra pravom, a ne samo socijalnom akcijom; radnici i njihove organizacije imaju pravo pozvati na štrajk; treba smanjiti broj kategorija radnika kojima je ovo pravo ograničeno; cilj štrajka je promocija i zaštita ekonomskih i socijalnih interesa radnika, čime se isključuju štrajkovi čiste političke naravi, dok se štrajkovi solidarnosti ne mogu izravno zabraniti; sudjelovanje u zakonitom štrajku ne smije imati za posljedicu sankcije bilo koje vrste i koje bi dovele do diskriminacije na temelju članstva u sindikatu (ILO, Freedom of Association: Digest of Decisions and Principles of the Freedom of Association Committee of the Governing body of the ILO, 1996, paras. 473-475).

8 Europska socijalna povelja (Narodne novine, Međunarodni ugovori, broj 15/2002) u našem pravnom poretku obvezuje od 31. prosinca 2002. Povelja je kao akt Vijeća Europe preuzeta od strane Europske unije kao pravna stečevina Europske unije.

9 O pravu na štrajk u međunarodnom paktu o ekonomskim, socijalnim i kulturnim pravima čovjeka, u konvencijama i drugim dokumentima Međunarodne organizacije rada te u Europskoj socijalnoj povelji vidjeti šire: Potočnjak, Ž., Pravo na štrajk, Naša zakonitost, br. 7-8, 1989., str. 852.-858.

10 Europska konvencija za zaštitu ljudskih prava i temeljnih sloboda i prateći protokoli (Narodne novine, Međunarodni ugovori, broj 18/1997, 6/1999, 8/1999, 14/2002, 13/2003, 9/2005, 1/2006 i 2/2010). Konvencija je potpisana u Rimu 4. studenog 1950. , a Republika Hrvatska je istoj pristupila 6. studenog 1996. (ratifikacija 17. listopada 1997.).

11 Povelja o temeljnim pravima Europske unije (čl. 27.) uređuje pravo na kolektivno pregovaranje i industrijske akcije kao legitimno sredstvo u zaštiti prava radnika.

12 Charter of Fundamental Rights of EU, OJ C364, od 18. prosinca 2000., opširnije: Bodiroga-Vukobrat, N., Barić, S., Povelja temeljnih ljudskih prava Europske unije s komentarom, Organizator, 2002.

13 Pročišćeni tekst EU-a i UFEU-a po stupanju na snagu Lisabonskog ugovora, OJ C83/114 od 30. ožujka 2010., dostupan na: http://old.hnb.hr/medjunarodna-suradnja/dokumenti/h-ugovor-o-eu-funkcioniranju-eu.pdf.

14 Primjerice, predmet C-438/05 ITWF v Viking Line, 2008, IRLR 143 te predmet C-341/05 Laval Un Partneri Ltd v Svenska Byggnadsarbetareforbundet, (2008), IRLR 160.

15 Case - Demir and Baykara v Turkey, ECHR (2008) 1345 (Ewing, K. D., Hendy, J., The dramatic implications of Demir and Baykara, Industrial Law Journal, 2010., vol. 39, br. 1, str. 44.-60.); Case - Enerji Yapi - Yol Sen v Turkey od 21. travnja 2009. 
U traženju odgovora na pitanje zakonitosti štrajka nužno je konzultirati nacionalne pravne poretke, u prvom redu ustavne tekstove ${ }^{16}$ (ne jamče svi ustavni tekstovi eksplicite pravo na štrajk ${ }^{17}$ ) i zakone, ${ }^{18}$ a shodno prihvaćenom načelu slobode ugovaranja u velikom broju pravnih sustava, ${ }^{19}$ odredbe o štrajku mogu biti i predmetom kolektivnog ugovora, ${ }^{20}$ iako isti u većini država u tom smislu imaju ograničenu ulogu. Međutim, neki pravni sustavi uopće ne predviđaju ni pravo na štrajk, niti granice njegove dopuštenosti, ${ }^{21} \mathrm{u}$ kom slučaju odlučujuću ulogu igra judikatura. ${ }^{22}$ Drugim riječima, pravna osnova prava na štrajk može biti nacionalni ustav, legislativa, sudska praksa i/ili kolektivni ugovori. ${ }^{23}$ U kontekstu zakonitosti štrajk je potrebno sagledati s aspekta prirode, pravnog karaktera i predmeta spora koji se štrajkom nastoji riješiti, zatim ovlasti organiziranja i provedbe štrajka, postupka organiziranja (najave štrajka, postupka mirenja, određivanja pravila o poslovima koji se ne smiju prekidati za vrijeme štrajka) te s obzirom na način njegove provedbe.

\section{PRAVNO DOPUŠTENI (ZAKONITI) ŠTRAJK - PRETPOSTAVKE}

U većini pravnih poredaka određene su pretpostavke koje se moraju ostvariti da bi štrajk bio zakonit. Međutim, budući da je pravo na štrajk u uskoj vezi s kolektivnim pregovaranjem, različita rješenja mogu postojati u nacionalnim pravnim sustavima. ${ }^{24}$ Naime, ako je kolektivno

16 Primjerice, francuski Ustav, točnije u paragrafu 7. preambule Ustava iz 1946. jamči se pravo na štrajk unutar pravnog okvira kojim se ovo pravo regulira. Istovjetno je i u Italiji (čl. 40. Ustava iz 1948.). U Sloveniji je u čl. 77. Ustava iz 1989. zajamčeno radnicima pravo na štrajk. Isto se može zakonom ograničiti radi zaštite javnog interesa, uzimajući pri tom u obzir vrstu i prirodu djelatnosti o kojoj je riječ.

17 Primjerice, austrijski Ustav (Staaatsgrundgesetz iz 1867.) u čl. 12. jamči svim austrijskim državljanima pravo na okupljanje i udruživanje; U Njemačkoj Ustav (Grundgesetz iz 1949. uz amandman iz 1993.) u čl. 9. (3) jamči pravo svakom pojedincu, odnosno zanimanju ili profesiji pravo na udruživanja radi zaštite i promicanja gospodarskih i radnih uvjeta.

18 U Austriji pravo na štrajk u privatnom sektoru regulirano je u sekciji 3. Arbeitsverfassungsgesetza iz 1973., dok u javnim službama to pitanje regulira Beamten-Dienstrechtgesetz.

19 U smislu odredbe čl. 9. ZR-a, kolektivnim se ugovorom mogu ugovoriti uvjeti rada koji su za radnika povoljniji od uvjeta određenih ZR-om ili drugim zakonom, a nepovoljniji od onih određenih zakonom samo ako zakon na to izričito ovlašćuje stranke kolektivnog ugovora. Ako je neko pravo iz radnog odnosa različito uređeno ugovorom o radu, pravilnikom o radu, sporazumom sklopljenim između radničkog vijeća i poslodavca, kolektivnim ugovorom ili zakonom, primjenjuje se za radnika najpovoljnije pravo, ako ZR-om ili drugim zakonom nije drukčije određeno.

20 U Francuskoj neki kolektivni ugovori ograničavaju pravo na štrajk namećući obvezu radnicima na postupak mirenja te da obavijeste poslodavca o pokretanju štrajka. No, pravila utvrđena u kolektivnom ugovoru ne obvezuju radnika pojedinca, budući da je pravo na štrajk individualno pravo koje se ne može ignorirati. U Njemačkoj se kolektivnim ugovorima najčešće reguliraju posljedice štrajka na način da se djelomično kompenziraju radnici koji su sudjelovali u štrajku. Međutim, ove odredbe znaju biti problematične s obzirom na to da mogu pomaknuti granice nezakonitih štrajkova. Što može biti predmet kolektivnog ugovora, uređeno je odredbom čl. 192. ZR-a.

21 Primjerice, u Nizozemskoj pravo na štrajk nije zajamčeno ni u jednom nacionalnom pravnom izvoru, no budući da je Nizozemska 1980. ratificirala Europsku socijalnu povelju iz 1961., 1953. Europsku konvenciju o zaštiti ljudskih prava te 1993. Konvenciju br. 98 Međunarodne organizacije rada, Vrhovni sud Nizozemske, pozivajući se na spomenute izvore, razvio je jurisprudenciju u pogledu navedenog prava (Odluka Vrhovnog suda od 30. svibnja 1986., SL 1986, 688, što je potvrđeno i u svojoj odluci od 22. studenog 1991., SL 1992, 508).

22 U Nizozemskoj odlučujuću ulogu glede priznanja prava na štrajk odigrao je Vrhovni sud Nizozemske, primjerice u presudi od 30. svibnja 1986., NJ 1986, 688, što je potvrđeno i presudom od 22. studenog 1991., NJ 1992., 508.

23 U Francuskoj pravo na štrajk u privatnom sektoru ne može biti regulirano kolektivnim ugovorom (Slučaj RJS 8-9/95 n 933 od 7. lipnja 1995.).

24 Upravo zbog različitosti nacionalnih pravnih sustava i velikog broja sporova glede dopuštenosti prava na štrajk Odbor za slobodu udruživanja pri Međunarodnoj organizaciji rada usvojio je sljedeće pretpostavke zakonitosti štrajka: obveza najave štrajka; 
pregovaranje u sferi heteronomne regulacije, onda će i pravo na štrajk, kao i granice njegove dopuštenosti biti dio korpusa istih pravnih pravila. No, ako se država ne miješa u regulaciju kolektivnog pregovaranja, nego je isto prepušteno autonomnom uređenju odnosnih socijalnih partnera, u tom slučaju pitanja vezana uz štrajk, u pravilu će također biti dijelom autonomnog izvora prava (kolektivnog ugovora). Nadalje, u tom pogledu važno je i pitanje tko ima pravo zastupanja interesa radnika, odnosno zaključenja kolektivnog ugovora, jer su upravo ti subjekti ujedno i aktivni subjekti štrajka. Daljnji čimbenik koji može utjecati na zakonitost štrajka jest karakter štrajka što mu ga priznaje nacionalni pravni sustav. Naime, isti se može smatrati sredstvom samoobrane koje može, ali i ne mora, nužno biti usmjereno prema vlastitom poslodavcu; sredstvo "samoosnaženja" ili svoje ishodište može imati u ljudskom dignitetu koje svakom pojedinom radniku jamči pravo na štrajk (individualno pravo). U odgovoru na pitanje zakonitosti štrajka valja uzeti u obzir i društveno-ekonomske uvjete. Naime, budući da se štrajk smatra sredstvom kojim svijet rada nastoji uspostaviti ravnotežu na tržištu rada sa svijetom kapitala, u današnjem globaliziranom svijetu poduzimanje štrajka kod jednog poslodavca koji je u izrazitoj ovisnosti o drugom poslodavcu (primjerice kod klastera), dovodi u pitanje pravu mjeru spomenute ravnoteže.

\subsection{SVRHA (RAZLOG, CILJ) PRAVNO DOPUŠTENOG ŠTRAJKA}

S obzirom na svrhu (razlog, cilj) koji se štrajkom nastoji postići isti se u pravnoj doktrini ${ }^{25}$ razlikuje prema prirodi, pravnom karakteru te predmetu spornog zahtjeva.

\subsubsection{DOPUŠTENOST ŠTRAJKA PREMA PRIRODI SPORNOG ZAHTJEVA}

Prema prirodi spornog zahtjeva razlikujemo gospodarske, odnosno socijalne i političke štrajkove. Svrha (razlog, cilj) gospodarskih, odnosno socijalnih štrajkova vezana je uz zaštitu i promicanje gospodarskih i socijalnih, odnosno profesionalnih ${ }^{26}$ interesa radnika. Usmjereni su protiv poslodavca radi ostvarenja boljih uvjeta rada (veća plaća, kraće radno vrijeme, bolja zaštita na radu) ili održanja postojećih. ${ }^{27}$ Pri tom nije riječ o pojedinačnom (individualnom),

obveza mirenja i /ili dobrovoljne arbitraže koje prethode pokretanju štrajka, koje se moraju provoditi adekvatno, nepristrano i žurno, a kojima se stranke mogu služiti na bilo kojem stupnju kolektivnog spora; obveza ostvarivanja kvoruma i donošenja sporazuma kvalificiranom većinom; obveza donošenja odluke o pokretanju štrajka tajnim glasovanjem; obveza usvajanja nužnih mjera za zaštitu sigurnosti dionika i prevenciju od nesreća; osiguravanje minimalnih usluga te jamstvo slobode rada za neštrajkaše. Vidi: ILO, Freedom od Association: Digest of decisions and principles of the Freedom of Association Committee of the Governing body of the ILO, Geneva, 1996., str. 500.-513.; 554.-558.; 586.

25 O granicama prava na štrajk vidjeti šire: Potočnjak, Ž., op. cit. u bilj. 2, str. 47.-73. O granicama prava na štrajk u državama članicama Europske unije vidjeti: Herman, V., Pravo na štrajk u državama članicama Europske unije, Pravni vjesnik, god. 19, br. 1-2, 2003., str. 325.-339.

26 Primjerice u francuskoj sudskoj praksi iskristalizirao se sadržaj pojma "profesionalni zahtjev": plaće (slučaj od 18. travnja 1989., Bull. Civ.V n ${ }^{\circ}$ 278); naknada za prekovremeni rad (RJS 10/96, n¹079 od 17. srpnja 1996.); loše grijanje kod poslodavca (RJS 1990/299, n419 od 4. travnja 1990.); protest protiv restrukturiranja poslodavca (slučaj od 20. svibnja 1992., Bull. civ. V n³19); pravo na organiziranje u sindikate (RJS 5/99, n²5, od 31.ožujka 1999.).

27 Štrajk kojem je cilj ostvarivanje boljih uvjeta rada, naziva se agresivni štrajk, a onaj kojem je cilj zadržati postojeće naziva se obrambeni štrajk. Šire vidjeti: Herman, V., op. cit. u bilj. 25, str. 326. 
nego o zajedničkom (kolektivnom) ${ }^{28}$ interesu radnika. U Republici Hrvatskoj, ${ }^{29}$ kao i u većini komparativnih pravnih poredaka, gospodarska, odnosno socijalna svrha štrajka jedna je od bitnih pretpostavki dopuštenosti štrajka. ${ }^{30}$

S druge strane, iako politički štrajkovi pogađaju poslodavce, isti su usmjereni protiv tijela vlasti neke države, odnosno političkih odluka koje ta tijela donose i to zbog svrhe koja najčešće nije u izravnoj vezi s pitanjima iz radnog odnosa. Zbog tog su takvi čisto politički štrajkovi zabranjeni u većini zemalja Europske unije. ${ }^{31}$ Međutim, zbog socijalne funkcije države, u praksi najčešće ne nailazimo na čisto političke štrajkove, već ti štrajkovi imaju mješoviti karakter (svrhu) i ne mogu se jasno razgraničiti od štrajkova koji imaju gospodarsku, odnosno socijalnu svrhu. Štoviše, pravna doktrina i sudska praksa u pojedinih država članica Europske unije daju temelj širenju granica dopuštenosti štrajkova koji sadrže političke elemente. ${ }^{32} \mathrm{U}$ smislu navedenog treba se odrediti i o generalnim štrajkovima za koje se u pravnoj doktrini ističe da “(...) predstavljaju državni protest ili protest određenog sektora, kojeg organizira sindikat kao odgovor na nacionalne ili granske prijedloge, ili djelovanje od strane privatnih ili javnih vlasti." ${ }^{33}$

U Republici Hrvatskoj ZR na općenit način određuje da sindikati imaju pravo pozvati na štrajk i provesti ga u svrhu zaštite i promicanja gospodarskih i socijalnih interesa svojih članova te zbog neisplate plaće, dijela plaće, odnosno naknade plaće, ako nisu isplaćene do dana dospijeća. ${ }^{34}$ Pravo na štrajk u slučaju spora o sklapanju, izmjeni ili obnovi kolektivnog ugovora dopušta samo sindikatu koji ima reprezentativnost. ${ }^{35}$ Nadalje, dopušta štrajk solidarnosti. ${ }^{36}$, ${ }^{37}$ Tumačeći upravo smisao navedenih odredbi ZR-a, sudska praksa u svakom pojedinom slučaju utvrđuje je li riječ o štrajku u kojem prevladavaju elementi pravom dopuštene svrhe. U

28 Kolektivni radni spor je spor između poslodavaca ili njihovih organizacija, s jedne strane te organizacija radnika (kolektiviteta radnika), s druge strane, u vezi s kolektivnim uređenjem radnih odnosa. Prema: Triva, S., Dika, M., Građansko parnično procesno pravo, Narodne novine, Zagreb, 2004., str. 793.

Čl. 205. ZR-a.

Prema Potočnjak, Ž., op. cit. u bilj. 2, str. 49. “u Njemačkoj, Velikoj Britaniji, Turskoj, Italiji, SAD, Poljskoj, Bugarskoj”.

Politički štrajk dopušten je u Austriji i Italiji, dok nije dopušten u Njemačkoj (Presuda Federalnog suda za radne sporove od 22. rujna 2009. - AZR 972/08), Francuskoj (slučaj Ets Panhard et Levassor c v Levern, Bull. Civ. V n 818 od 8. listopada 1960.) te u smislu zakonske regulative u Nizozemskoj. Međutim, prema pravnom shvaćanju nizozemskog Vrhovnog suda, politički štrajk treba sagledavati u okvirima Europske socijalne povelje (European Social Charter) i takav štrajk je dopušten sve dok se odnosi na pitanja vezana za rad (pitanja koja su obično objekt pregovaranja između poslodavca i radnika, pa čak i ako poslodavac ne može utjecati na odluke koje donosi javna vlast). Slično i šire vidjeti: Burger, F., The Right to Strike: Austria, str. 123.-124., Kessler, F., The Right to Strike: France, str. 217.; Waas, B., The Right to Strike: Germany, str. 239.-240., Pascucci, P., The Right to Strike: Italy, str. 336., Houwerzijl, M., Roozendaal, W., The Right to Strike: Netherlands, str. 417.-418., u: Waas, B. (ed.) The right to strike, A comparative view, Wolters Kluwer Law and Business, 2014.

Slično i šire vidjeti: Herman, V., op. cit. u bilj. 25, str. 326. i Potočnjak, Ž., op. cit. u bilj. 2, str. 52.-58.; Houwerzijl, M., Roozendaal, W., op. cit. u bilj. 31, str. 417.-418. U Italiji Ustavni sud priznaje zakonitost tzv. ekonomsko-političkim štrajkovima, kojima se nastoji utjecati na usvajanje mjera kojima bi se izravno utjecalo na poboljšanje uvjeta rada radnika (Presuda talijanskog Ustavnog suda br. 290/1974.). No, iako ove restrikcije i dalje postoje, talijanski Kasacijski sud priznao je svojstvo zakonitosti čak i čistom političkom štrajku s aspekta građanskog prava (Presuda talijanskog Kasacijskog suda odbr. 16515/2004).

33 Herman, V., op. cit. u bilj. 25, str. 326.; Marinković Drača, D., Štrajk - priručnik za sindikate i poslodavce, TIM pres, Zagreb, 2005. , str. 35.

34 Čl. 205. st. 1. ZR-a.

35 St. 2.

36 St. 3.

37 Ministarstvo rada u pravnom mišljenju broj Klasa: 110-01/11-01/244, Ur. broj: 526-08-01-01/5-11-2 cijeni da je odredba čl. 269. st. 1. ZR-a/09 dispozitivne naravi, na način da se prava i obveze iz radnog odnosa koja se tiču štrajka dodatno mogu urediti drugim pravnim izvorima. 
tom smislu stajalište pravne doktrine je da "poslodavac ne bi smio trpjeti štetne posljedice štrajka zbog razloga na koje on ne može utjecati, niti ih riješiti u mirenju osim kod štrajka solidarnosti. Međutim, isti bi mogli biti usmjereni protiv akata vlasti, pod uvjetom da se radi o propisima koji inače predstavljaju materiju kolektivnog ugovora te ako je Vlada RH stranka kolektivnog ugovora prema posebnom zakonu." ${ }^{38,39}$

Generalni štrajk nije uređen kao poseban oblik štrajka u Republici Hrvatskoj pa prema stručnom mišljenju Ministarstva rada i socijalne skrbi i nije riječ o štrajku u užem smislu, ${ }^{40}$ već o obliku pritiska sindikata, legitimnom u smislu konvencija MOR-a br. 87. i 98. o slobodi udruživanja i zaštiti prava na organiziranje, odnosno primjeni načela prava na organiziranje i kolektivno pregovaranje. ${ }^{41}$ U sudskoj praksi Vrhovnog suda Republike Hrvatske zauzeto je pravno shvaćanje prema kojem je štrajk dopušteno pravno sredstvo samo u slučaju kolektivnog spora koji proizlazi iz sukoba interesne naravi o pitanju koje nije pravno uređeno, a reguliranje tog pitanja može biti predmetom kolektivnog ugovora. ${ }^{42}$

\subsubsection{DOPUŠTENOST ŠTRAJKA PREMA PRAVNOM KARAKTERU SPORNOG ZAHTJEVA}

Prema pravnom karakteru spornog zahtjeva razlikuju se štrajkovi u vezi s interesnim zahtjevima koji nisu pravno uređeni (interesni kolektivni radni sporovi) i štrajkovi u vezi sa zahtjevima koji su pravno uređeni ${ }^{43}$ (pravni kolektivni radni sporovi).

Kod interesnih kolektivnih sporova sporni zahtjev nije pravno uređen (ne postoji pravno pravilo na temelju kojeg bi se o postavljenom zahtjevu moglo odlučiti), pa se ne može riješiti u sudskom ili drugom postupku u kojem se mogu rješavati pravni sporovi. Najčešće se javljaju u pogledu donošenja, izmjene, obnove ili dopune kolektivnih ugovora kojima se uređuju uvjeti rada (plaća, radno vrijeme, zaštita na radu, odmori i sl.). Predstavljaju pravno dopušteno sredstvo za unaprjeđenje gospodarskih i socijalnih uvjeta radnika na radu.

$S$ druge strane, pravni kolektivni radni sporovi nastaju u pogledu tumačenja ili primjene određene pravne norme (zakona, odnosno kolektivnog ugovora). Kao takvi mogu se rješavati

38 Frntić, D. F.; Gović Penić, I.; Hanzalek, D.; Milković, D.; Novaković, N.; Rožman, K., Detaljni komentar Zakona o radu, Radno pravo, Zagreb, 2016., str. 1046., Rožman, K., op. cit. str. 20.

39 "Iako promicanje i zaštita gospodarskih i socijalnih interesa članova, na prvi pogled predstavlja vrlo široku definiciju razloga za štrajk, mišljenja smo da se štrajk u prvom redu može organizirati radi spora zbog sklapanja, izmjene ili obnove kolektivnog ugovora te eventualno nekih drugih pitanja kojima se reguliraju odnosi između poslodavca i radnika odnosno sindikata. U tom smislu držimo da nije dopušten štrajk protiv zakona, odnosno protiv prijedloga zakona." Mišljenje Ministarstva gospodarstva, rada i poduzetništva od 4. srpnja 2011. g. (izvor: http://www.iusinfo.hr/OfficialPosition/Content.aspx?SOPI=MMIN201D2011 0704N42\&Doc=MMIN-HR, pristupljeno 16. kolovoza 2017.). Stručno mišljenje Ministarstva rada i socijalne skrbi Republike Hrvatske Klasa: 110-01/03-01/18, Urbroj: 524-04/2-03-2 od 16. siječnja 2003.

41 Prema daljnjem obrazloženju Ministarstva, "o štrajku u užem smislu se ne radi zato što nije poznato kojim poslodavcima ga treba najaviti, jer se radi o neizvjesnom događaju i o donošenju Zakona iz ustavnog djelokruga Hrvatskog sabora za postupak mirenja ne postoji poslodavac u ulozi stranke, niti poslodavci mogu otkloniti razlog štrajka, a nepoznati krug poslodavaca ne može sklopiti ni sporazum o poslovima koji se za vrijeme štrajka ne smiju prekidati."

43 Ne mogu se ugovoriti prava koja ne ulaze u slobodu ugovaranja jer su propisana kogentnom normom ZR-a ili drugog posebnog zakona. Takva se prava ne bi primjenjivala i u okolnostima kada su povoljnija za radnike. 
u sudskom postupku ili sredstvima mirnog rješavanja spora, pa su u većini pravnih poredaka štrajkovi kojima se nastoji riješiti ovaj vid sporova nedopušteni (zabranjeni). ${ }^{44},{ }^{45}$

Uz to, štrajk treba biti organiziran u skladu s pravilima sindikata koji štrajk organizira. ${ }^{46},{ }^{47}$

Kako je navedeno, u Republici Hrvatskoj ZR svojim odredbama ${ }^{48}$ dopušta štrajkove u vezi s interesnim zahtjevima koji nisu pravno uređeni (radi promicanja gospodarskih i socijalnih interesa), ali ne i zbog ispunjenja već nastalih pravno uređenih prava. ${ }^{49}$ Tek iznimno, dopušta štrajk u vezi sa zahtjevima koji su pravno uređeni i to samo zbog neisplate plaće, dijela plaće, odnosno naknade plaće, ako nisu isplaćene do dana dospijeća. U pravnoj doktrini se ističe da bi se štrajk zbog neisplate plaće, dijela plaće ili naknade mogao organizirati samo zbog neisplate nesporne plaće, dijela plaće ili naknade, ali ne i zbog neisplate plaće, dijela plaće ili naknade koje su sporne. ${ }^{50},{ }^{51}$

\subsubsection{DOPUŠTENOST ŠTRAJKA PREMA PREDMETU SPORNOG ZAHTJEVA}

Da bi se u cijelosti moglo izvršiti razgraničenje između pravno dopuštenog i nedopuštenog štrajka prema njegovoj svrsi (razlogu, cilju), uz izloženo razlikovanje prema prirodi i pravnom karakteru spornog zahtjeva, štrajk je potrebno sagledati i s aspekta predmeta spornog zahtjeva. Naime, mogućnost štrajka može se ograničiti prema zahtjevu čiji je predmet ograničavanje prerogativa poslodavca (pitanja u sferi isključive nadležnosti poslodavca); prema zahtjevu čiji predmet nije samostalan zahtjev, već potpora nekom drugom štrajku (štrajk solidarnosti) ${ }^{52}$ te štrajk zbog (sklapanja, izmjene ili dopune) kolektivnog ugovora, tj. zbog tzv. interesnih kolektivnih radnih sporova.

44 U Njemačkoj i Nizozemskoj je dopušten interesni štrajk, ali ne i onaj u vezi sa zahtjevima koji su pravno uređeni. S druge strane, u Austriji su dopušteni štrajkovi i zbog interesnih i pravnih kolektivnih sporova. Vidi: Burger, F., op. cit. u bilj. 31, str. 123.-124.; Waas, B., op. cit. u bilj. 31, str. 239.-240.; Houwerzijl, M., Roozendaal, W., op. cit. u bilj. 31, str. 417.-418.; Potočnjak, Ž., op. cit. u bilj. 2, str. 60. "u Njemačkoj, Austriji, Švicarskoj, Švedskoj, Danskoj...”.

.
promicanja gospodarskih i socijalnih interesa članova sindikata, ali ne i zbog ispunjenja pravno uređenih i već nastalih prava koja se mogu ostvariti u sudskom postupku. Ovom izmjenom štrajk je dopušten i u slučaju neisplate plaće, odnosno naknade plaće protekom roka od 30 dana od dana dospijeća. Izmjena je obrazložena shvaćanjem da neisplata plaće nije samo pravno pitanje, već su time ugroženi kolektivno-gospodarski i socijalni interesi radnika. ZR/09 odredbom čl. 269. st. 1. dopušta mogućnost štrajka zbog plaće, odnosno naknade plaće ako nisu isplaćene protekom roka od 30 dana od dana dospijeća.

Tako prema: Frntić, D. F.; Gović Penić, I.; Hanzalek, D.; Milković, D.; Novaković, N.; Rožman, K., op. cit. u bilj. 38, str. 1048.; Rožman, K., op. cit. str. 21. "(...) on se ne bi smio organizirati ako je poslodavac isplatio sve, a radnici misle da je trebao još nešto."

51 Vidjeti pravna shvaćanja sudske prakse zauzeta u odlukama: VSRH broj: Gž-16/00 od 10. svibnja 2000., Revr-583/03 od 20. siječnja 2004. i Gž-3/97 od 17. travnja 1997.

52 U pravnoj doktrini se za dopuštenost štrajka s obzirom na predmet spora vrši raščlamba i za štrajkove o sindikalnom organiziranju i razgraničenju te štrajkove u vezi sa sindikalnom sigurnošću (Potočnjak, Ž., op. cit. u bilj. 2, str. 69.-73.) koju s obzirom na regulativu čl. 165.-221. ZR-a, kao i obujam i cilj ovog rada, ne smatramo relevantnom za naše pravno područje. 
Glede ograničenja s obzirom na zahtjeve čiji je predmet izuzet kao isključiva nadležnost poslodavca, doktrina i sudska praksa pravnih sustava u kojima se ta ograničenja primjenjuju, ${ }^{53}$ temelje se na shvaćanju prema kojem je razvoj poduzetništva moguć samo u okolnostima u kojima radnici i njihove organizacije nemaju mogućnost štrajkom utjecati na donošenje poslovnih odluka koje treba prepustiti u isključivu nadležnost poslodavca. Riječ je o zahtjevima koji se odnose na odluke vezane za određivanje rukovodećeg osoblja kod poslodavca, zasnivanje i prestanak radnog odnosa, organizaciju i raspored poslova, sudjelovanje u određenom poslu, investiranju i sl. Ako je predmet spornog zahtjeva izuzet kao isključiva nadležnost poslodavca, štrajk je nedopušten.

Štrajkovi solidarnosti su posebna vrsta štrajka u kojem njegovi sudionici nemaju poseban zahtjev koji se odnosi na poboljšanje njihova gospodarskog i socijalnog položaja, ali se pridružuju zahtjevu (solidariziraju se) sa sudionicima nekog drugog, primarnog štrajka (zahtjev se odnosi na gospodarske i socijalne poboljšice radnika). ${ }^{54}$ Kako se ovim štrajkom u spor uvodi i poslodavac koji nije u mogućnosti odlučiti o zahtjevu primarnog štrajka, to pojedini pravni sustavi imaju načelno negativno shvaćanje prema njihovoj zakonitosti. ${ }^{55}$ Međutim, zbog sve veće koncentracije korporacija i globalizacije gospodarstva štrajkovi solidarnosti sve su učestaliji. U tom smislu Vijeće eksperata MOR-a drži da bi opća zabrana štrajka solidarnosti mogla dovesti do zlouporaba. ${ }^{56}$ Stoga, radnici trebaju imati mogućnost ostvarivanja ovog prava pod uvjetom zakonitosti primarnog štrajka.

53 Tako se prema praksi koji razvijaju sudovi u Švedskoj u isključivoj je nadležnosti poslodavca odlučivati o zasnivanju i prestanku radnog odnosa, upravljanju i distribuciji rada, kao i o osobi koja će biti predradnik kod poslodavca (Adlercreutz, A., Sweden. International Encyclopaedia for Labour Law and Industrial Relations, Deventer, Kluwer, Vol. 9, 1982., str. 186. i 187.). No, prerogativi poslodavca mogu biti predmetom uređenja kolektivnog ugovora, a ako isti nisu eksplicite regulirani kolektivnim ugovorom, presumira se da su implicitno regulirani u obliku "tihe klauzule". U Njemačkoj je pravna doktrina zauzela shvaćanje da su odluke o sudjelovanju u određenom poslu, investiranju i slično u isključivoj nadležnosti poslodavca (Weiss, M., Labour Law and Industrial Relations in the Federal Republic of Germany, Deventer, Kluwer Law and Taxation Publishers, 1987., str. 120.-122.). Međutim, budući da je slobodno poduzetništvo u Njemačkoj zajamčeno Ustavom, štrajkovi kojima se to pravo ograničava mogu biti proglašeni nezakonitima, kao i štrajkovi kojima je predmet sprječavanje poslodavca da zatvori poduzeće. No, oni štrajkovi o kojima bi u tom kontekstu bio predmet ublažavanje posljedica zatvaranja poduzeća za radnike okvalificirali bi se kao zakoniti. O štrajkovima koji se odnose na pitanja iz isključive nadležnosti poslodavca vidjeti šire: Potočnjak, Ž., op. cit. u bilj. 2, str. 63. i 64.

54 Slično i šire vidjeti: Učur, M. Đ., Smokvina, V., Industrijske akcije kao sindikalna prava i slobode, Zbornik Pravnog fakulteta Sveučilišta u Rijeci (1991.) v. 31, br. 2, (2010.), str. 692., Potočnjak, Ž., op. cit. u bilj. 2, str. 65. i 66., Ruždjak, M., Zakon o radu komentar, sudska praksa, primjeri ugovora o radu i općih akata, Poslovni zbornik, Zagreb, 2005., str. 414.

55 Prema: Gorman, R. A., Basic Text on Labor Law, Unionisation and Collective Bargaining, St. Paul, Minnesota, West Publishing Company, 1976., str. 306., u SAD-u je štrajk ili druga industrijska akcija nedopuštena ako se poduzima u obliku sekundarnog bojkota; U Francuskoj primjerice postoji distinkcija između štrajka solidarnosti koji se poduzima unutar istog poduzeća i onog koji se poduzima radi davanja podrške izvan njega. U prvom slučaju moraju biti zadovoljeni kolektivni interesi za štrajkaše, primjerice ako štrajkaju zbog osobno uvjetovanog otkaza nekog radnika koji je opravdan, u tom slučaju bi štrajk bio nezakonit (slučaj Boultam v Sté Norinco, Bull.civ., n405), međutim ako je riječi o neopravdanom otkazu, štrajk bi bio zakonit (slučaj Sté Créations Hénon vCarneva, Bull.civ.V, n599). Drukčije je postupanje ako se štrajk solidarnosti poduzima radi davanja podrške izvan poslodavca, u tom slučaju takav štrajk ima više političke konotacije te je potrebno da sud u takvim slučajevima ispita koliko je jaka veza između grupa štrajkaša glede njihova zajedničkog interesa (slučaj od 23.listopada 1969., Bull.Crim., $\mathrm{n}^{\circ} 267$ ), u Njemačkoj su dopušteni štrajkovi solidarnosti (Federalni sud za radne sporove u presudi od 19. lipnja 2007., Az:1 AZR 396/06=NZA 2007, 1055); u Italiji Ustavni sud tumačenjem prava koje jamči čl. 40. talijanskog Ustava, daje karakter zakonitosti i štrajkovima solidarnosti (presuda talijanskog Ustavnog suda br. 123/1962.); u Nizozemskoj budući da nema posebne regulative koja uređuje pitanje prava i granice dopuštenosti štrajka, izravno je primjenjiva Europska socijalna povelja, točnije klauzula 6.4., na temelju koje Odbor stručnjaka Europske socijalne povelje smatra da štrajk solidarnosti ulazi u sferu zakonitog štrajka. No nizozemski Vrhovni sud ima restriktivnije tumačenje u presudi Panhonlibco (presuda Vrhovnog suda od 15. siječnja 1960., NJ 1960., 84) u kojoj štrajkove solidarnosti smatra u pravilu nezakonitima, a samo iznimno, u posebnim okolnostima, zakonitima, dok niži sud u drugom slučaju ima još restriktivnije shvaćanje smatrajući da štrajkovi solidarnosti ne ulaze u domenu klauzule 6.4. Europske socijalne povelje (presuda Amsterdamskog suda od 26. kolovoza 1998., KG 1998, 257). 
Kada je riječ o ograničenjima koja se mogu tumačiti u okviru predmeta zahtjeva, opće odredbe ZR-a izrijekom (sudska praksa je i prije novele koja štrajk zbog kolektivnog ugovora izrijekom uređuje smatrala da je riječ o štrajku čija je svrha promicanje gospodarskih i socijalnih interesa) ${ }^{57}$ reguliraju štrajk zbog kolektivnog ugovora te izričito dopuštaju štrajk solidarnosti. ${ }^{58}$ Naime, u regulativi kojom se određuju sindikati ovlašteni organizirati štrajk zbog kolektivnog ugovora ${ }^{59}$ navodi se mogućnost organiziranja i provedbe štrajka u slučaju spora o sklapanju, izmjeni ili obnovi kolektivnog ugovora, dok se štrajk zbog otkaza kolektivnog ugovora ne navodi. Tako je u dijelu pravne doktrine izražena dvojba je li navedenom odredbom isključena mogućnost štrajka zbog otkaza kolektivnog ugovora. ${ }^{60}$ No, držimo da navedenu odredbu treba tumačiti ekstenzivno (u smislu dopuštenosti štrajka i u slučaju spora zbog otkaza kolektivnog ugovora).

Štrajk solidarnosti se, prema ZR-u, mora najaviti poslodavcu kod kojeg se organizira, smije započeti bez provedbe postupka mirenja, ali ne prije isteka roka od dva dana računajući od dana početka štrajka u čiju se potporu organizira. No, temeljni uvjet zakonitosti ovog vida štrajka jest zakonitost primarnog štrajka u čiju potporu se isti organizira. Tako, u okolnostima kada je zabranjen primarno organizirani štrajk treba prekinuti i štrajk solidarnosti (nedopuštenost /nezakonitost/ primarno organiziranog štrajka predmnijeva i nedopuštenost /nezakonitost/ štrajka solidarnosti) ${ }^{61}$

\subsubsection{AKTIVNI I PASIVNI SUBJEKTI ŠTRAJKA}

Glede pitanja je li priznato pravo na štrajk pravo (ovlaštenje) radnika ili sindikata različit je pristup, kako u pravnoj doktrini, ${ }^{62}$ tako i u implementaciji ovog načela u zakonskoj regulativi različitih pravnih sustava. ${ }^{63}$ Polazeći od činjenice da je pravo na štrajk povijesno utemeljeno uz pravo radnika na sindikalno organiziranje, u većini zemalja ovlast organiziranja štrajka imaju

4 B), International Labour Conference, 81 st Session, Geneva, 1994, para 168.

57 VSRH broj: Gž-18/14 od 17. srpnja 2014., Gž-11/10 od 30. travnja 2010. Isto tako u odluci Gž-20/14 od 18. srpnja 2014 ističe se: "Pravi smisao i svrha štrajka je pravo i mogućnost sindikata da sredstvima pritiska štiti i promiče interese svojih članova, posebno prilikom kolektivnih pregovaranja. To znači, pregovarati u cilju sklapanja kolektivnog ugovora, pa propuštanje mogućnosti iznalaženja rješenja u postupku mirenja i nedefiniranja sadržaja kolektivnog ugovora, opravdava poduzimanje štrajka."

58 Čl. 205. st. 2., 3. i 5. ZR-a.

59 Čl. 205. st. 2. ZR-a.

60 Frntić, D. F.; Gović Penić, I.; Hanzalek, D.; Milković, D.; Novaković, N.; Rožman, K., op. cit. u bilj. 38, str. 1047.; Rožman, K., op. cit. str. 21.

61 Vidjeti pravna shvaćanja sudske prakse zauzeta u odlukama: Sud Europske unije, (Veliko vijeće), C 438/05 od 11. prosinca 2007., VSRH broj: Rev-1452/97 od 26. rujna 1997. i Gž-1/97 od 8. siječnja 1997.

62 O različitom doktrinarnom pristupu ovom pitanju vidjeti: Potočnjak, Ž., op. cit. u bilj. 2, str. 22., 23., 72.-7., 268.-271.

63 Zemlje romanskog pravnog kruga svoju normativu zasnivaju na pravnom shvaćanju da je pravo na štrajk povezano uz građanske slobode i dopuštaju štrajkove koji nisu sindikalno organizirani. U zemljama germanskog pravnog kruga, kao i zemljama čiji se pravni poredak temelji na anglosaksonskom pravu, samo je dopušten štrajk kojeg organizira sindikat. U vezi s ovim pitanjem ZR je prihvatio koncepciju kakva postoji u Njemačkoj i Švedskoj. Vidjeti šire: Rozić, I., Kolektivno radno pravo, JP NIO Službeni list BiH, Sarajevo, 2013., str. 164. 
sindikati. ${ }^{64}$ Takav pristup prihvaćen je u zakonodavstvu ${ }^{65}$ Republike Hrvatske te sudskoj praksi bez ekstenzivnog tumačenja ove odredbe. Naime, jedinstveno je pravno shvaćanje na kojima sudovi temelje svoje odluke da su nedopušteni svi spontano organizirani štrajkovi u kojima sudjeluju skupine sindikalno neorganiziranih radnika ili u kojima bez prethodne odluke ovlaštenog tijela sindikata sudjeluju i sindikalno organizirani radnici. ${ }^{66}$

Ovlast organizirati štrajk u svrhu promicanja gospodarskih i socijalnih interesa svojih članova ${ }^{67}$ te zbog neisplate plaće, dijela plaće, odnosno naknade plaće, ako nisu isplaćene do dana dospijeća (bez iznimke za štrajk solidarnosti), imaju svi sindikati. Međutim, štrajk u slučaju spora o sklapanju, izmjeni ili obnovi kolektivnog ugovora (štrajk zbog kolektivnog ugovora), ${ }^{68}$ pravo pozvati na štrajk i provesti ga imaju samo sindikati kojima je u skladu s posebnim propisom utvrđena reprezentativnost za kolektivno pregovaranje ${ }^{69}$ i sklapanje kolektivnog ugovora i koji su pregovarali o sklapanju kolektivnog ugovora. ${ }^{70}$ Dakle, navedene pretpostavke moraju biti ispunjene kumulativno, pa sindikati koji nemaju svojstvo reprezentativnosti, odnosno reprezentativni sindikati koji nisu sudjelovali u pregovorima, ne mogu organizirati štrajk.

S obzirom na to da je pravo na štrajk jedno od ustavnih prava radnika, u pravnoj doktrini ${ }^{71}$ zastupljena su shvaćanja da se navedenom normativom ZR-a prava radnika na štrajk ograničavaju šire nego što to ustavna jamstva dopuštaju. Pri tom posebno treba istaknuti da prema izričitoj odredbi ZR-a, ${ }^{72}$ radničko vijeće ne smije sudjelovati u pripremanju ili ostvarenju štrajka, isključenja s rada ili druge industrijske akcije, niti se smije na bilo koji način miješati u kolektivni radni spor koji može dovesti do takve akcije.

Pravo sudjelovati u štrajku koji je ovlašteno organiziran imaju članovi sindikata koji je štrajk organizirao, ali i radnici koji su članovi drugog sindikata koji nije organizirao štrajk te radnici koji nisu članovi sindikata. Bitno je da svaki radnik ima slobodu odlučivanja želi li pristupiti štrajku (ne smije biti prisiljen sudjelovati u štrajku). ${ }^{73}$ Činjenica da su radnici prisiljeni sudjelovati u štrajku prouzročila bi nezakonitost tog štrajka. ${ }^{74}$

64 Tako je u Njemačkoj (Otto, H., Arbeitskampf und Schlichtingsrecht, C. H. Beck, 2006., str. 71.); Italiji (talijanski Ustav, čl. 39. para. 1; Zakon br.146/1990 izmijenjen Zakonom br. 83/2000); Francuskoj (Carta, L., Dechamps, M.; Janin, A.; Le Luduec, a. L., France, $u$ : The right to strike. A comparative perspective. A study of national law in six EU states, The institute of employment rights, 2009., str. 35.); Nizozemskoj pozivajući se na klauzulu 6.4. Europske socijalne povelje. U Austriji štrajkove obično provode sindikati, ali nije isključena mogućnost da i sindikalno neorganizirani radnici pokrenu štrajk, iako se to u praksi rijetko događa (Burger, F., op. cit. u bilj. 31, str. 123.).

Čl. 205. st. 1. ZR-a.

66 VSRH br. Gž-16/99 od 15. lipnja 1999.

67 O štrajkovima organiziranim u svrhu promicanja gospodarskih i socijalnih interesa vidjeti šire supra pod II.1.1.

68 O štrajku u slučaju spora o sklapanju, izmjeni ili obnovi kolektivnog ugovora vidjeti šire supra pod II.1.1.

69 Reprezentativnost se utvrđuje prema Zakonu o reprezentativnosti udruga poslodavaca i sindikata (Narodne novine, broj 93/2014 i 26/2015 - dalje: Zakon o reprezentativnosti). d.o.o. Zagreb, Zagreb, 2010., str. 659.; Marinković Drača, D; Štrajk op. cit. u bilj. 33, str. 32. i 33. 
Ovisno o svrsi (razlogu, cilju) zbog koje se štrajk organizira, štrajk može biti usmjeren protiv poslodavca ili udruge poslodavaca. U pravnoj doktrini posebno je izvršena raščlamba okolnosti kada na pasivnoj strani može biti Vlada Republike Hrvatske, ali ne u statusu tijela javne (izvršne) vlasti, već u statusu zastupnika poslodavaca. ${ }^{75},{ }^{76}$

\subsubsection{POSTUPAK ORGANIZIRANJA I PROVEDBE ŠTRAJKA}

Da bi štrajk bio zakonit, osim navedenih materijalnopravnih pretpostavki za njegovu dopuštenost (pravno dopuštena svrha/cilj štrajka) te da je organiziran od osobe koja je na to ovlaštena, štrajk treba biti organiziran i proveden u skladu s propisanim postupkom. ${ }^{77}$ Postojanje kogentnih odredbi u nacionalnim zakonodavstvima o organiziranju i provedbi štrajka (postupku) u skladu je s citiranim međunarodno prihvaćenim pravilima o štrajku kao temeljnom pravu radnika. Međutim, u pravnoj doktrini opravdano se ističe da taj postupak nikako ne bi smio biti složen i spor i na taj način praktički štrajk onemogućio ili bi gubio na svojoj učinkovitosti. ${ }^{78}$ Zakonitost postupka organiziranja štrajka sagledava se kroz sljedeće faze: donošenje odluke o štrajku i određivanja zahtjeva; najava štrajka; provođenje postupka mirnog rješenja spora; korištenje drugih oblika industrijske akcije; provođenje postupka određivanja pravila o poslovima koji se ne smiju prekidati za vrijeme štrajka; poštovanja klauzula industrijskog mira; način provedbe štrajka te njegove društvene prihvatljivosti. U nastavku teksta analiziramo navedene faze u Republici Hrvatskoj uspoređujući ih s rješenjima u nekoliko komparativnih pravnih sustava.

\subsubsection{ODLUKA O ŠTRAJKU, ODREĐIVANJA ZAHTJEVA TE NAJAVA ŠTRAJKA}

ZR legitimira sindikate kao ovlaštenike organiziranja štrajka (aktivne subjekte štrajka). Nadalje, sindikat koji organizira štrajk mora u najavi štrajka naznačiti razloge (svrhu, cilj) štrajka. Da bi štrajk bio zakonit, mora se najaviti ${ }^{79}$ poslodavcu, odnosno udruzi poslodavaca protiv koje je usmjeren, a štrajk solidarnosti poslodavcu kod kojeg se taj štrajk organizira. $.^{80}, 81$

75 Vidjeti šire Frntić, D. F.; Gović Penić, I.; Hanzalek, D.; Milković, D.; Novaković, N.; Rožman, K., op. cit. u bilj. 38, str. 1046. i 1047.; Marinković Drača, D., op. cit. u bilj. 33, str. 33. i 34.

76 U vezi s pitanjem osoba koje su ovlaštene organizirati, provesti i sudjelovati u štrajku vidjeti pravna shvaćanja sudske prakse zauzeta u odlukama: VSRH broj: Gž-6/98 od 22. travnja 1998., Gž-42/99 od 10. svibnja 2000., Gž-321/03 od 25. ožujka 2003., Gž-22/10 od 8. rujna 2010. i Gž-2/03 od 5. ožujka 2003.

77 Štrajk treba biti organiziran u skladu s pravilima sindikata koji štrajk organizira. Statut sindikata shodno odredbi čl. 172. st. 3. ZR-a mora sadržavati odredbe o tijelima ovlaštenima za sklapanje kolektivnog ugovora te uvjetima i postupku organiziranja industrijskih akcija. Vidjeti pravna shvaćanja sudske prakse zauzeta u odlukama: VSRH broj: Gž-5/05 od 27. travnja 2005. i Gž-5/00 od 13. travnja 2000.

Drača, D., op. cit. u bilj. 33, str. 38.

79 U Francuskoj zahtjevi radnika moraju biti poznati poslodavcu prije nego što štrajk započne (Kessler, F., op. cit. u bilj. 31, str. 218.-220.) te se štrajk mora najaviti poslodavcu najmanje pet dana prije početka štrajka u koji rok se ne računa dan objave (slučaj Pouget v Sté Unigard, Bull.civ., n³91). U tom razdoblju strane su obvezne na pregovore (Code de travail, L 521.3, para.5). U Sloveniji odluka o proglašenju i početku štrajka treba sadržavati i precizne zahtjeve radnika (Končar, P., The Right to Strike, op. cit. u bilj. 31, str. 470.-471.).

$80 \quad \check{C}$ l. 205. st. 3. ZR-a.

81 Različito je u komparativnim pravnim porecima. Tako u austrijskom pravu ne postoji obveza posebne najave niti razdoblje čekanja u kojem bi se spor trebao riješiti obveznim postupkom mirenja ili posredovanja (Burger, F., The Right to Strike, op. cit. u bilj. 31, str. 124.). U francuskom pravu prestanak rada može započeti u svakom trenutku otkad je poslodavac obaviješten o 
To može učiniti samo ovlašteno tijelo sindikata određeno statutom sindikata. Naime, prema izričitoj odredbi ZR-a, ${ }^{82}$ statut udruge mora sadržavati odredbe o tijelima ovlaštenima za sklapanje kolektivnog ugovora te uvjetima i postupku organiziranja industrijskih akcija. U tom smislu, kada je riječ o štrajku radi sklapanja granskog kolektivnog ugovora, isti bi se trebao najaviti, kako udruzi poslodavaca protiv koje je usmjeren (udruga poslodavaca je u ovom slučaju druga strana s kojom se provodi postupak mirenja), tako i svakom pojedinom poslodavcu kod kojeg će se štrajk provoditi. Ratio odredbe o obvezi sindikata da štrajk najavi poslodavcu ima za svrhu umanjiti materijalne gubitke za poslodavca koji bi mogli nastati u tijeku provedbe štrajka na način da na vrijeme prilagodi svoje poslovne aktivnosti štrajku. Važno je napomenuti da ZR posebno ne propisuje rok u kojem najava treba prethoditi štrajku, pa ako se štrajk najavljuje nakon mirenja, štrajk će prema ovoj osnovi biti zakonit iako je najava izvršena dan prije štrajka. No, valja postaviti pitanje: postiže li se ovakvim tumačenjem ratio donošenja navedene odredbe? Smatramo da se dužina roka treba odrediti u ovisnosti o veličini poslodavca, budući da je samorazumljivo da prilagodba poslovnih aktivnosti štrajku većeg poslodavca iziskuje dulje razdoblje. Međutim, ako se štrajk najavljuje prije mirenja, a stranke se nisu drukčije sporazumjele, najava treba prethoditi štrajku u roku koji uključuje pet dana mirenja. ${ }^{83}$ Najava treba biti u pisanu obliku i sadržavati razloge za štrajk, mjesto, dan i vrijeme početka štrajka te način njegove provedbe. ${ }^{84},{ }^{85}$

\subsubsection{KADA ŠTRAJK SMIJE ZAPOČETI?}

Štrajk se ne smije započeti prije okončanja postupka mirenja, odnosno prije provedbe drugog postupka mirnog rješavanja spora o kojem su se stranke sporazumjele. ${ }^{86}, 87 \mathrm{u}$ kolektivnom

zahtjevima radnika. Međutim, ti zahtjevi moraju biti poznati poslodavcu prije nego što štrajk započne, no forma te obavijesti nije pravno regulirana. Zahtjev može biti upućen poslodavcu preko radnika koji sudjeluju u štrajku ili sindikata, ali i preko inspektora rada. Međutim, u javnom sektoru štrajk može biti pokrenut od strane reprezentativnog sindikata nakon obavijesti dane pet dana prije štrajka (Kessler, F., The Right to Strike, op. cit. u bilj. 31, str. 218.-220.). U Italiji je obveza davanja obavijesti o štrajku zakonom predviđena isključivo za štrajk koji se odnosi na bitne javne službe. Takva najava se ne može dati kasnije od deset dana prije štrajka (Pascucci, P., The Right to Strike, op. cit. u bilj. 31, str. 337.). U Nizozemskoj se štrajk mora najaviti što je moguće prije, ovisno o prirodi spornog zahtjeva (Houwerzijl, M., Roozendaal, W., The Right to Strike, op. cit. u bilj. 31, str. 418.-420.). U Sloveniji Odbor za štrajk prethodno mora obavijestiti poslodavca o namjeri štrajka, i to kada je riječ o privatnom sektoru pet dana prije štrajka, u javnom sektoru sedam dana te posebnim djelatnostima (vojska, policija) deset dana prije početka štrajka (Končar, P., The Right to Strike, op. cit. u bilj. 31, str. 470.-471.).

82 Čl. 172. st. 3. ZR-a.

83 Ako se strane nisu drukčije sporazumjele, mirenje se prema odredbi čl. 208. ZR-a mora dovršiti u roku od pet dana od dana dostave obavijesti o sporu Gospodarsko-socijalnom vijeću (u daljnjem tekstu: GSV) ili uredu državne uprave u županiji, odnosno uredu Grada Zagreba nadležnom za poslove rada.

84 Čl. 205. st. 6. ZR-a.

85 Vidjeti pravna shvaćanja sudske prakse zauzeta u odlukama: VSRH broj: Gž-13/13 od 14. svibnja 2013., Gž- 12/15 od 17. 6. 2015., Gž - 6/98 od 22. 4. 1998., Gž - 18/14 od 17. 7. 2014. i Ustavnog sud RH broj: U - III - 1937/2004 od 13. listopada 2004.

86 Čl. 205. st. 4. i čl. 206. ZR-a.

87 Austrijsko pravo ne sadrži posebne pretpostavke kod organiziranja i provedbe štrajka, ali se kolektivnim ugovorom može ugovoriti prethodna obveza mirenja ili arbitražno rješavanje spora (Burger, F., The Right to Strike, op. cit. u bilj. 31, str. 124.). U francuskom pravu, tijekom razdoblja najave štrajka, stranke imaju obvezu pregovaranja (Kessler, F., The Right to Strike, op. cit. u bilj. 31, str. 218.). U njemačkom pravu postupovni zahtjevi nisu propisani zakonom, ali sudska praksa primjenom načela razmjernosti zahtjeva da sva sredstva pregovaranja moraju biti upotrijebljena prije nego što sindikat započne sa štrajkom. Međutim, takvo tumačenje ograničeno je slobodom sindikata da štrajk započne i prije nego što proglasi neuspjeh u pregovaranju (dovoljno je da sindikat jednostavno pokrene akciju štrajka). Prema daljnjem shvaćanju sudske prakse dopušteno je odmah pokrenuti industrijsku akciju i bez prethodnih pregovora, ako je poslodavac od samog početka takve pregovore odbio (Waas, B., The Right to Srike, op. cit. u bilj. 31, str. 240.-242.). Talijansko pravo kod sektora javnih usluga predviđa da štrajku mora 
ugovoru ili posebnim sporazumom (ugovorom). Izuzetak je predviđen za štrajk solidarnosti koji se može započeti i bez provedbe postupka mirenja, ali ne prije isteka roka od dva dana od početka štrajka u čiju se potporu organizira. ${ }^{88}$

Posebno je regulirano da se štrajk zbog neisplate plaće, dijela plaće, odnosno naknade plaće može organizirati ako nisu isplaćene do dana dospijeća. ${ }^{89}$ Ako kolektivnim ugovorom ili ugovorom o radu nije drukčije određeno, plaća i naknada plaće za prethodni mjesec isplaćuju se najkasnije do petnaestog dana u idućem mjesecu, ${ }^{90}$ pa se štrajk u kolektivnim pravnim radnim sporovima u vezi s isplatom plaće ne može organizirati prije proteka tog roka.

\subsubsection{MIRNO RJEŠENJE SPORA}

Budući da bi, kako je istaknuto, štrajk trebao biti ultima ratio zbog potencijalne ugroze interesa, ne samo stranaka u sporu, nego i trećih pa i općih, nacionalnih interesa, stranke tog odnosa, kao i država (kogentnim normama) u zaštiti općih interesa, utvrđuju načine provedbe mirnog rješenja spora glede ostvarivanja suprotstavljenih zahtjeva radnika i poslodavca, koji trebaju prethoditi samom štrajku. Naime, stranke su ovlaštene sporazumno urediti način mirnog rješavanja nastalog spora koji može dovesti do štrajka (ili drugog oblika industrijske akcije), a ako takav sporazum ne postoji mora se provesti Zakonom propisani postupak mirenja. ${ }^{91}$ Stoga, ZR uređuje postupak mirenja, ali i mogućnost da stranke postupak mirenja okončaju sporazumom, učinke tog sporazuma, kao i mogućnost rješidbe kolektivnog radnog spora arbitražom.

\subsubsection{POSTUPAK MIRENJA}

Ako nije riječ o štrajku solidarnosti te ako stranke spora nisu dogovorile neki drugi način njegova mirnog rješavanja, štrajk ne smije započeti prije okončanja postupka mirenja. Mirenje provodi miritelj kojeg su stranke sporazumno izabrale s liste koju utvrđuje Gospodarsko-socijalno vijeće ${ }^{92}$ ili druga osoba izvan te liste koju stranke sporazumno odrede. ${ }^{93}$ Način izbora miritelja, provođenje postupka mirenja i obavljanje organizacijskih, stručnih i administrativnih poslova za potrebe toga postupka uređen je Pravilnikom o načinu izbora miritelja i provođenju

prethoditi provedba postupka mirenja (Pascucci, P., The Right to Strike, op. cit. u bilj. 31, str. 337.). Nizozemsko pravo izričito regulira obvezu pregovora u kojima je moguće doći do sporazuma prije štrajka (Houwerzijl, M., Roozendaal, W., The Right to Strike, op. cit. u bilj. 31, str. 418.-420.), a slično je i u slovenskom pravu koje predviđa obvezu pokušaja mirnog rješavanja spora od trenutka otkad je štrajk najavljen (Končar, P., The Right to Strike, op. cit. u bilj. 31, str. 470.- 471.).

Čl. 205. st. 5. ZR-a.

Čl. 205. st. 1. ZR-a je izmijenjen u odnosu na normativu čl. 269. st. 1. ZR-a/95 koji je predviđao mogućnost štrajka zbog plaće, odnosno dijela plaće, ali tek ako nisu isplaćene protekom roka od trideset dana od dana dospijeća.

Čl. 92. st. 3. ZR-a.

Čl. 206. st. 1. ZR-a.

Listu miritelja u skladu s kogentnom odredbom ZR-a (čl. 206. ZR-a) svojom odlukom utvrđuje Gospodarsko-socijalno vijeće, pri kojem se lista i vodi (čl. 207. st. 1. i 2.).

Čl. 206. ZR-a. 
postupka mirenja u kolektivnim radnim sporovima, ${ }^{94}$ koji shodno obvezi i ovlasti, ${ }^{95}$ donosi ministar nadležan za radne odnose. Nakon provedenog postupka mirenja, pisani prijedlog rješenja pitanja sastavlja u dogovoru sa strankama koji taj prijedlog i potpisuju, miritelj u dogovoru sa strankama izrađuje prijedlog rješenja spora te određuju rok za njegovo prihvaćanje ili odbijanje, ${ }^{96}$ a stranke potpisuju. Sklapanjem sporazuma o spornim pitanjima okončan je postupak mirenja. No, ako se stranke u sporu ne odazovu pozivu miritelja, miritelj je dužan obavijestiti GSV da postupak mirenja nije proveden, a ako se stranke u sporu odazovu pozivu miritelja, a postupak mirenja ne bude uspješno okončan, miritelj će po isteku roka predviđenog za postupak mirenja obavijestiti GSV da je postupak mirenja proveden, ali nije uspješno okončan. ${ }^{97}$ Ako se stranke u sporu nisu drukčije sporazumjele, postupak mirenja mora se dovršiti u roku od pet dana ${ }^{98}$ od dostave obavijesti o sporu GSV-u ili nadležnom uredu. Kada nastali spor stranke u ovom roku nisu sporazumno riješile, smatra se da postupak mirenja nije uspio. $.^{99}, 100$

\subsection{POSEBNO O SPORAZUMU KOJIM STRANKE OKONČAVAJU POSTUPAK MIRENJA}

Stranke postupak mirenja mogu okončati sporazumom u kom slučaju će isti, ako se odnosi na sklapanje, izmjenu ili obnovu kolektivnog ugovora, imati pravnu snagu i učinke kolektivnog ugovora. ${ }^{101}$ Međutim, u praksi se može dogoditi da sporazum sklope samo neki od više reprezentativnih sindikata koji u svom članstvu nemaju više od pedeset posto radnika članova od ukupno sindikalno organiziranih radnika kod reprezentativnih sindikata, a što je potrebno da bi kolektivni ugovor bio važeći prema Zakonu o reprezentativnosti. ${ }^{102} \mathrm{Da}$ bi se otklonilo navedeno nesuglasje, Pravilnikom o mirenju ${ }^{103}$ regulirano je da takav sporazum ima pravnu snagu i učinke kolektivnog ugovora ako ga potpišu sindikati u sporu koji u svom članstvu imaju kvalificiranu većinu u skladu s posebnim propisom. U protivnom, njegovim potpisivanjem, započinje postupak pregovora o sklapanju, izmjeni ili obnovi kolektivnog ugovora u skladu

94 Pravilnikom o načinu izbora miritelja i provođenju postupka mirenja u kolektivnim radnim sporovima (Narodne novine, broj 130/2015 - u daljnjem tekstu: Pravilnik o mirenju).

Čl. 207. st. 3. ZR-a.

96 Čl. 14. Pravilnika o mirenju.

97 Čl. 15. i 16. Pravilnika o mirenju.

98 “(...) pet dana, ali ne u roku od pet radnih dana (...)", vidjeti pravna shvaćanja sudske prakse zauzeta u odluci VSRH broj: Gž12/15 od 17. lipnja 2015.

99 Čl. 208. ZR-a, čl. 13. Pravilnika o mirenju. Vidjeti pravna shvaćanja sudske prakse zauzeta u odlukama: VSRH broj: Gž-1/02 od 16. siječnja 2002., Gž-9/01 od 15. svibnja 2001., P - 2/00 od 10. svibnja 2000., Gž-11/10 od 30. travnja 2010., Gž-2/07 od 19. ožujka 2007., Gž-9/01 od 15. svibnja 2001., Rev - 2839/99 od 3. studenog 1999. te Županijskog suda u Zagrebu broj: Pnz-10/06 od 17. lipnja 2006.

Čl. 209. st. 1. i 2. ZR-a.

100 Međutim, stranke u sporu mogu u svakom trenutku sporazumno predložiti miritelju prekid postupka mirenja kako bi im se omogućilo da samostalno i sporazumno riješe nastali spor, a koje razdoblje prekida postupka se ne ubraja u rok za provođenje postupka mirenja (čl. 12. Pravilnika o mirenju).

101 Čl. 209. st. 1. i 2. ZR-a.

102 Čl. 25. Zakona o reprezentativnosti.

103 Čl. 17. Pravilnika o mirenju. 
s posebnim propisom. U ovom dijelu osnovano je u pravnoj doktrini ${ }^{104}$ iznesena dvojba je li navedena odredba Pravilnika o mirenju u suglasju s odredbom čl. 209. st. 2. ZR-a. Naime, kako je navedeno, ista nije usklađena s odredbama Zakona o reprezentativnosti, pa bi u praksi primjenom na konkretan slučaj trebalo neposredno primijeniti odredbe ZR-a, tj. postupiti prema odredbi čl. 37. Ustavnog zakona o Ustavnom sudu Republike Hrvatske. ${ }^{105}$ Zbog toga je de lege ferenda potrebno izmijeniti odredbu čl. 209. st. 2. ZR-a stipulacijom iz odredbe čl. 17. Pravilnika o mirenju.

Ako je sporazum postignut u slučaju spora zbog neisplate plaće, dijela plaće, odnosno naknade plaće do dana dospijeća, njime se može ugovoriti način i dinamika njihove isplate. Međutim, u pravnoj doktrini ${ }^{106}$ opravdano se ističe da takav sporazum ne otklanja obvezu poslodavca da radnicima dostavi obračun iznosa koje je bio dužan isplatiti, ${ }^{107}$ a koji ima snagu ovršne isprave. ${ }^{108}$

\subsubsection{ARBITRAŽNO RJEŠAVANJE SPORA}

Stranke mogu rješavanje kolektivnog radnog spora sporazumno povjeriti arbitraži. ${ }^{109}$ Pri tom se imenovanje arbitra ili arbitražnog vijeća, pitanje koje se iznosi pred arbitražu, ${ }^{110}$ kao i druga pitanja arbitražnog postupka, mogu urediti kolektivnim ugovorom ili sporazumom stranaka sklopljenim nakon nastanka spora. Na ostala pitanja vezana uz arbitražu, a koja nisu posebno uređena ZR-om, primjenjuje se Zakon o arbitraži. ${ }^{111}$ Pravorijek arbitražnog suda ima prema strankama snagu pravomoćne sudske presude. ${ }^{112},{ }^{113}$ Kada je riječ o sporu o primjeni zakona, drugog propisa ili kolektivnog ugovora, arbitraža temelji svoju odluku na zakonu, drugom propisu ili kolektivnom ugovoru, a u sporovima o sklapanju, izmjeni ili obnovi kolektivnog ugovora (u kojem slučaju arbitražna odluka ima pravnu snagu i učinke kolektivnog ugovora), arbitraža će svoju odluku temeljiti na pravičnosti. ${ }^{114}$ Protiv arbitražne odluke nije

104 Frntić, D. F.; Gović Penić, I.; Hanzalek, D.; Milković, D.; Novaković, N.; Rožman, K., op. cit. u bilj. 38, str. 1059. i 1060.

105 Prema odredbi čl. 37. Ustavnog zakona o Ustavnom sudu Republike Hrvatske (Narodne novine, broj 99/1999, $29 / 2002$ i 49/2002), ako sud u postupku utvrdi da zakon koji bi trebao primijeniti, odnosno pojedina njegova odredba, nisu suglasni s Ustavom, zastat će s postupkom i podnijeti Ustavnom sudu zahtjev za ocjenu suglasnosti zakona, odnosno pojedine njegove odredbe s Ustavom, a ako sud u postupku utvrdi da drugi propis koji bi trebao primijeniti, odnosno pojedina njegova odredba, nisu suglasni s Ustavom i zakonom, na konkretan slučaj će neposredno primijeniti zakon, a Ustavnom sudu će podnijeti zahtjev za ocjenu suglasnosti spornog propisa, odnosno pojedine njegove odredbe s Ustavom i zakonom.

106 Frntić, D. F.; Gović Penić, I.; Hanzalek, D.; Milković, D.; Novaković, N.; Rožman, K., op. cit. u bilj. 38, str. 1061.

107 Kako to nalaže odredba čl. 93. st. 2. ZR-a.

108 U skladu s odredbom čl. 93. st. 3. ZR-a.

109 Čl. 210. st. 1. i 2. ZR-a.

110 Čl. 211. ZR-a.

111 Zakon o arbitraži (Narodne novine, broj 88/2001 - dalje: Zakon o arbitraži).

112 Čl. 31. Zakona o arbitraži, čl. 212. st. 4. ZR-a.

113 Mogućnost tužbe za poništaj pravorijeka, kao ograničeno izvanredno pravno sredstvo protiv arbitražnog pravorijeka, uređena je odredbom čl. 36. Zakona o arbitraži.

114 Čl. 212. st. 1., 2. i 5. ZR-a. 
dopuštena žalba ${ }^{115}$ te mora biti obrazložena, osim ako stranke spora u kolektivnom ugovoru ili sporazumu o iznošenju spora pred arbitražu nisu odredile drukčije. ${ }^{116},{ }^{117}$

\subsubsection{DOPUŠTENA I NEDOPUŠTENA SREDSTVA U KOLEKTIVNOJ RADNOJ BORBI}

Štrajk je najznačajnija i svakako najčešća industrijska akcija radnika i njihovih sindikata. Međutim, kod suprotstavljenih interesa radnika i poslodavaca, radnici osim štrajka mogu koristiti i druge oblike industrijskih akcija kao što su bojkot, ${ }^{118}$ radnička straža (picketing), ${ }^{119}$ javno demonstriranje te label. No, neki su oblici industrijskih akcija, budući da im nedostaje element kolektivne obustave rada, nedopušteni, odnosno ako se koriste u tijeku štrajka, potonji čine nezakonitim. Navedeni zabranjeni oblici industrijskih akcija za posljedicu mogu imati otkaze ugovora o radu radnika koji su sudjelovali u takvoj akciji, budući da su se isti obvezali poslodavcu na bona fide postupanje tijekom trajanja radnog odnosa. Ovdje možemo podvesti sitnu sabotažu, ${ }^{120}$ različite oblike pasivnog otpora (rezistencije) ${ }^{121}$ samovoljno vršenje rada te usporavanje rada pretjeranom marljivošću. Poslodavac na zakoniti štrajk može odgovoriti industrijskom akcijom - isključenjem s rada (lockout), koji predstavlja "prekid rada koji uzrokuje jedan ili više poslodavaca zatvarajući poduzeće u namjeri prisiljavanja radnika da se odreknu svojih zahtjeva ili da prihvate zahtjeve poslodavca". ${ }^{122}$

Iako ZR svojim odredbama preciznije uređuje samo štrajk ${ }^{123}$ te uz odgovarajuću primjenu odredbi o štrajku i isključenje s rada (lockout $)^{124}$ u pravnoj doktrini se osnovano ističe mo-

115 Prema odredbi čl. 31. Zakona o arbitraži, pravorijek arbitražnog suda ima prema strankama snagu pravomoćne sudske presude, osim ako su se stranke izričito sporazumjele da se pravorijek može pobijati pred arbitražnim sudom višeg stupnja, što je prema posebnom uređenju iz odredbe čl. 212. st. 4. ZR-a kod kolektivnog radnog spora isključeno.

116 Čl. 212. st. 3. i 4. ZR-a. Prema odredbi čl. 30. st. 3. Zakona o arbitraži, pravorijek se izrađuje u pisanom obliku i on mora biti obrazložen osim ako su se stranke sporazumjele da obrazloženje nije potrebno ili ako je pravorijek donesen na temelju nagodbe stranaka (nagodbe u smislu odredbe čl. 29. istog Zakona).

117 U Austriji ne postoje izričite zakonske odredbe glede obveznog arbitražnog rješavanja industrijskih sporova, dok se u individualnim slučajevima spor može povjeriti arbitraži (Burger, F., The Right to Strike, op. cit. u bilj. 31, str. 126.-127.). Mogućnost da se kolektivni radni spor povjeri arbitraži predviđa francusko pravo, Zakonik o radu, čl. L 525-1 (Kessler, F., The Right to Strike, op. cit. u bilj. 31, str. 231.-232.), njemačko (Waas, B., The Right to Strike, op. cit. u bilj. 31, str. 257.), talijansko (Pascucci, P., The Right to Strike, op. cit. u bilj. 31, str. 347.), nizozemsko (Houwerzijl, M., Roozendaal, W., op. cit. u bilj. 31, str. 425.) i slovensko pravo (Končar, P., op. cit. u bilj. 31, str. 474.-476.).

118 U Italiji se bojkot u kontekstu inkriminirajućih kaznenih odredbi koje se odnose na štrajk sankcionira (talijanski Kazneni zakonik, čl. 507.).

119 U Italiji je piketing nezakonit ako uključuje akcije obilježene prijetnjama ili nasiljem usmjerene prema načinu izvedbe rada neštrajkaša (presuda Kasacijskog suda od 10. ožujka 1983.); u Nizozemskoj dopušten, jer ulazi u domenu temeljnih ljudskih prava, kao što su sloboda govora, demonstriranja i okupljanja.

120 U Italiji se sabotaža kazneno sankcionira sukladno čl. 508., st. 2. Kaznenog zakonika.

121 U pravnoj doktrini se kao daljnji oblici industrijskih akcija navode: detaljno postupanje prema pravilima poslodavca ili struke, usporavanje intenziteta rada te neizvršavanje određenih poslova. O drugim industrijskim akcijama različitim od štrajka vidjeti šire: Učur, M. Đ., Smokvina, V., Industrijske akcije kao sindikalna prava i slobode, Zbornik Pravnog fakulteta Sveučilišta u Rijeci (1991.) v. 31., br. 2, 2010., str. 693.-698.; Potočnjak, Ž., Pravo na štrajk, Pravni fakultet u Zagrebu, Savez samostalnih sindikata Hrvatske, Zagreb, 1992., str. 15., 229.-250. i 280.

122 Birk, R., Industrial Conflict: The Law of Strikes and Lock-outs, Comparative Labour Law and Industrial Relations, Deventer, Kluwer Law and Taxation Publishers, 1985., str. 400.; Detaljnije o lockoutu: Potočnjak, Ž., op. cit. u bilj. 2, str. 240.-247.

123 Čl. 205. ZR-a.

124 Čl. 213. ZR-a. 
gućnost da se bojkot i drugi oblici industrijske akcije pobliže urede kolektivnim ugovorom, ${ }^{125}$ odnosno aktima Gospodarsko-socijalnog vijeća. ${ }^{126}, 127$

\subsubsection{PRAVILA O POSLOVIMA KOJI SE NE SMIJU PREKIDATI ZA VRIJEME ŠTRAJKA}

Kako bi poslodavac zaštitio poslovanje na način koji mu omogućava obnavljanje rada neposredno nakon završetka štrajka (proizvodno - održavajući poslovi), ili/i kako bi za vrijeme štrajka mogao obavljati poslove koji su prijeko potrebni radi sprječavanja ugrožavanja života, zdravlja ili osobne sigurnosti pučanstva (nužni poslovi), dužan je do dana okončanja postupka mirenja predložiti sindikatu sporazumnu izradu i donošenje pravila o navedenim koji se ne smiju prekidati za vrijeme štrajka (ili isključenja s rada) i broju radnika koji će ih obavljati za to vrijeme. Određivanjem ovih poslova ne smije se onemogućiti ili bitno ograničiti pravo na štrajk. ${ }^{128}$

Ako sindikat i poslodavac u roku od petnaest dana od dana dostave prijedloga ne postignu sporazum, u daljnjem roku petnaest dana mogu zatražiti da o tim poslovima odluči arbitraža u sastavu od jednog predstavnika sindikata, jednog predstavnika poslodavca te neovisnog predsjednika kojeg stranke sporazumno određuju. Ako se ne mogu sporazumjeti o imenovanju predsjednika arbitražnog vijeća, a ta pitanja nisu drukčije uređena kolektivnim ugovorom ili sporazumom stranaka, istog imenuje predsjednik suda koji bi bio nadležan za zabranu štrajka u prvom stupnju. Arbitraža je dužna odluku donijeti u roku od petnaest dana od dana pokretanja arbitražnog postupka, a ako jedna strana u tom postupku odbija sudjelovati, postupak će se provesti bez njezina sudjelovanja, u kojem slučaju odluku donosi predsjednik arbitražnog vijeća. ${ }^{129}$

Navedenom regulativom omogućeno je poslodavcu da organizira poslovanje na način na koji će mu štrajk prouzročiti manju štetu. S druge strane, propisani postupak izrade i donošenja pravila ne onemogućava niti ograničava pravo na štrajk. No, važno je istaknuti da budući da je, prema odredbama ZR-a, štrajk dopušten u kolektivnim pravnim radnim sporovima $u$ vezi s neisplatom plaće, navedeno uređenje omogućava poslodavcu zlouporabu postupka kod ove vrste štrajka. Naime, čak i da se arbitraža odmah pokrene nakon što dogovor nije postignut u roku od petnaest dana od dana dostave prijedloga, cijeli postupak traje najmanje trideset dana, što kod štrajka zbog neisplate plaće, dijela plaće, odnosno naknade plaće predstavlja predugo razdoblje. Stoga bi i kod ovog vida spora i ostalih koji mogu dovesti do štrajka i drugih oblika industrijske akcije de lege ferenda bila primjerenija normativa prema kojoj bi poslodavac utvrđivanje poslova kod ovog vida štrajka mogao predložiti odmah po registraciji sindikata koji bi kod njega djelovao. Navedeni poslovi utvrdili bi se posebnim pravilnikom donesenim prema istoj proceduri i u rokovima koji su predviđeni važećim ZR-om. Svaka eventualna izmjena vršila bi se prema istoj proceduri. Time bi poslodavac sigurnije zaštitio svoje poslova-

\footnotetext{
125 U smislu odredbe čl. 192. ZR-a.

126 U smislu odredbe čl. 221. ZR-a.

127 Učur, M. Đ., Smokvina, V., Industrijske akcije kao sindikalna prava i slobode, Zbornik Pravnog fakulteta Sveučilišta u Rijeci (1991.), god. 31, br. 2, 2010., str. 699.

128 C̆l. 214. st. 1.-3. i 9. ZR-a.

129 Čl. 214. st. 4.-8. ZR-a.
} 
nje, ali i olakšao, odnosno ubrzao postupak organiziranja i provedbe štrajka. Ako su pravila o poslovima koji se ne smiju prekidati donesena, sindikat ih se mora pridržavati. U protivnom bi poslodavac mogao zahtijevati zabranu štrajka te ostvarenje ostalih prava koja mu pripadaju na temelju nezakonitog štrajka. ${ }^{130}$

\subsubsection{KLAUZULE SOCIJALNOG (INDUSTRIJSKOG) MIRA}

Većina pravnih sustava presumira relativnu klauzulu industrijskog mira prema kojoj za ona pitanja koja su već regulirana kolektivnim ugovorom nije dopušteno pokretati industrijske akcije, tj. štrajk odnosno lockout za cijelo vrijeme važenja kolektivnog ugovora. Navedena obveza može proizlaziti iz heteronomnog izvora (primjerice zakona), kolektivnog ugovora ili iz nekog drugog sporazuma socijalnih partnera. Apsolutna klauzula industrijskog mira dolazi do izražaja u autonomno uređenom postupku mirnog rješavanja spora. ${ }^{131} \mathrm{~S}$ obzirom na različite pristupe u različitim pravnim sustavima u teoriji radnog prava razlikujemo sljedeće klauzule industrijskog mira: implicitna i eksplicitna, relativna i apsolutna, materijalna i procesna te potpuna i ograničena. ${ }^{132}$

\subsubsection{PROVEDBA ŠTRAJKA}

Da bi štrajk bio zakonit, mora se provoditi na način koji je pravno dopušten. S obzirom na način provedbe štrajka u pravnoj teoriji razlikujemo kružne štrajkove ${ }^{133}$ isprekidane, ${ }^{134}$ štraj-

130 Vidjeti pravna shvaćanja sudske prakse zauzeto u odluci VSRH broj: Gž-4/03 od 7. svibnja 2003.

131 U Austriji gotovo svi kolektivni ugovori sadrže klauzulu industrijskog mira tijekom trajanja kolektivnog ugovora. Kršenje takvih odredbi može dovesti do kršenja ugovora (Burger, F., op. cit. u bilj. 31, str. 124.-125.). Različito je u francuskom pravu koje ne poznaje klauzule industrijskog mira. U pravnoj teoriji se polazi od shvaćanja da je pravo na štrajk zajamčeno ustavom, pa se kolektivnim ugovorom ovo pravo ne može zakonito zabraniti (Kessler, F., op. cit. u bilj. 31, str. 220.). U njemačkom pravu apsolutna zabrana štrajka (razdoblje apsolutnog industrijskog mira) nije predviđena, ali je takav uglavak dopušten u kolektivnim ugovorima. S druge strane, relativna obveza mira se presumira u svim kolektivnim ugovorima, pa i onda kada nema eksplicitnog dogovora oko toga (Waas, B., op. cit. u bilj. 31, str. 242.-243.). U Italiji, prema mišljenju većine, nema implicitne obveze mira, pa u tom smislu nema ograničenja za poziv i organiziranje štrajka koji se odnosi na pitanja koja su već uređena kolektivnim ugovorom, dok je apsolutna obveza mira dopuštena jedino ako je izričito propisana kolektivnim ugovorom (Pascucci, P., op. cit. u bilj. 31, str. 337.-338.). U Nizozemskoj kolektivni ugovori mogu sadržavati klauzulu mira-zabrane bilo kakvih industrijskih akcija dok je kolektivni ugovor na snazi. Ako takva dužnost u kolektivnom ugovoru nije posebno ugovorena, ista se smatra implicitnom obvezom prema kojoj stranke kolektivnog ugovora neće koristiti kolektivne industrijske akcije kako bi drugu stranu prisilile na ponovno razmatranje uvjeta kolektivnog ugovora, dok je isti na snazi (Houwerzijl, M., Roozendaal, W., op. cit. u bilj. 31, str. 420.-421.). U Sloveniji je pravo na štrajk Ustavom utemeljeno kao individualno pravo radnika. Može biti ograničeno jedino statutom, pa čak i kada je klauzula mira ugovorena kolektivnim ugovorom, takva klauzula ne sprječava radnike kao nositelje tog prava na štrajk (Končar, P., op. cit. u bilj. 31, str. 471.).

132 Detaljnije: Potočnjak, Ž., Pravo na štrajk, str. 107.-117.

133 U Francuskoj su zakoniti. Vidi slučaj Sté Montale v Lemaire (Bull.civ., n¹33 od 25. veljače 1988.). U Italiji su se kružni, kao i isprekidani štrajkovi sve do donošenja presude talijanskog Kasacijskog suda br. 711/1980 smatrali nezakonitima. U navedenoj presudi Sud drži da se zakonitim štrajkom smatra svaka kolektivna obustava rada radnika sa svrhom postizanja zajedničkog cilja te svako ograničenje glede obuhvata obustave rada, kao i njegovih učinaka. U Nizozemskoj su zakoniti, jer Vrhovni sud smatra da pada u okvir klauzule 6.4. Europske socijalne povelje (presuda Vrhovnog suda od 30.svibnja 1986, NJ 1986, 688 (NS), para.3.6).

134 Kod isprekidanog štrajka nenajavljeno često dolazi do prekida rada u određenom razdoblju, ali na kraće vrijeme. Vidjeti šire: Buklijaš, B., Kolektivno radno pravo, Pravni fakultet Sveučilišta u Splitu, Split, 2012., str. 153. 
kove upozorenja ${ }^{135}$ te iznenađenja. ${ }^{136}$ Bez obzira na to o kojoj je vrsti riječ način poduzimanja štrajka mora biti takav da nije nasilan, da se njime ne oštećuju pretjerano interesi poslodavca te da se njime ne smeta posjed. U protivnom bi štrajk bio nezakonit. Nadalje, u sudskim postupcima različitih država pri ispitivanju dopuštenosti štrajka analizira se je li primijenjeno načelo ultima ratio prema kojem se prije pokretanja industrijske akcije štrajka moraju iscrpiti sva sredstva pregovaranja i mirnog rješavanja spora te test proporcionalnosti, ${ }^{137}$ prema kojem kolektivne akcije moraju biti primjerene osiguranju postignuća legitimnog cilja i ne smiju ograničavati temeljne slobode ako to nije prikladno, nužno i razumno.

ZR ne uređuje način provedbe štrajka. Radnici bi se u provedbi štrajka morali pridržavati pravila koja je u najavi sindikat naznačio, a koja ne smiju biti u suprotnosti s kogentnim zakonskim odredbama, odnosno odredbama kolektivnog ugovora. Nadalje, ZR određuje da je štrajk kolektivna obustava rada, no pri tom ne određuje treba li obustava biti potpuna ${ }^{138}$ ili djelomična. Također, ne postoji zabrana da su radnici, iako ne rade, i dalje nazočni na svojim radnim mjestima, da su skupno u zgradi ili ispred zgrade poslodavca i sl. Ako način provedbe štrajka nije precizno uređen kolektivnim ugovorom, zakonitost istog procjenjivat će sud u svakom pojedinačnom slučaju u okvirima općeg određenja štrajka kao oblika industrijske akcije te opće pravne zaštite (zabrane počinjenja kaznenih djela i prekršaja, ostvarenja subjektivnih stvarnih prava poslodavca i sl., da nije riječ o nasilnim radnjama te onima koje vrijeđaju tuđa subjektivna stvarna prava ili smetaju nečiji posjed), što može dovesti do različitih rješenja u istim situacijama, a time do pravne nesigurnosti.

Podnormiranost načina provedbe zakonitog štrajka nadomještaju pravna shvaćanja sudova zauzeta u postupcima po zahtjevima sudske zabrane nezakonitog štrajka. Tako se prema shvaćanju suda prekid rada radnika može smatrati štrajkom i kada nije u cijelosti prekinut; ${ }^{139}$ poduzimanje nedopuštenih radnji, poput blokade rada skladišta poslodavca, u okviru samog izvođenja akcije štrajka, za posljedicu ima nezakonitost štrajka; ${ }^{140}$ karakter štrajka ima i akcija radnika u kojoj rad nije prekinut u cijelosti; ${ }^{141}$ i dugotrajno odbijanje rada unatoč fizičkoj prisutnosti unutar poduzeća ima obilježja osobito teške povrede ugovora o radu, neovisno o tome ima li odbijanje rada obilježja štrajka; ${ }^{142}$ incidentne situacije pojedinačnih radnika koji su

135 Zakoniti su u Francuskoj. U Nizozemskoj su nezakoniti, budući da ne odgovaraju načelima lojalne radne prakse sukladno kojoj je suprotnu stranu potrebno obavijestiti o pokretanju štrajka kako bi mogla limitirati štetu.

136 Štrajkovi koji se provode bez prethodne najave poslodavcu. Vidjeti šire: Buklijaš, B., op. cit. u bilj. 134, str. 153.

137 U Njemačkoj bilježimo ekstenzivnu uporabu načela ultima ratio i testa proporcionalnosti. Naime, štrajk će prema stajalištu suda biti nezakonit ako je evidentno da njegovo poduzimanje nije bilo ni nužno niti primjereno u postizanju cilja koji se njime želio ostvariti. No, s druge strane štrajk će biti zakonit u situaciji u kojoj je pokrenut štrajk bez prethodno provedenog postupka pregovora kada je od samog početka razvidno da ih druga strana odbija (Presuda Federalnog suda za rad od 14. veljače 1989. 1AZR 142/88). U Nizozemskoj su sudovi djelomično skloni primjenjivati test proporcionalnosti, budući da je samorazumljivo da će poslodavac u slučaju štrajka pretrpjeti štetu (presuda od 11. studenog 1994., NJ 1995., 152.). No, ako je provedbom štrajka za poslodavca nastala strukturalna ili dugotrajna šteta, odnosno ako je nastala šteta trećima odnosno javnom interesu, u tom slučaju može se govoriti o disproporcionalnosti štrajka. Također, suci su dužni ispitati jesu li prije pokretanja štrajka iscrpljene sve ostale mogućnosti rješidbe kolektivnog spora (Presuda Vrhovnog suda Nizozemske od 22. siječnja 2000., JAR 2000/63 Douwe Egberts).

138 U Francuskoj obustava rada mora biti potpuna (RJS 8-9/91 n998 od 25. lipnja 1991.).

VSRH broj Gž-16/00 od 10. svibnja 2000.

VSRH broj: Gž-16/00 od 10. svibnja 2000.

VSRH broj: Rev-2682/00 od 22. kolovoza 2001. 
sudjelovali u štrajku, gledajući u cjelini, ipak predstavljaju samo pojedinačne, ekscesne slučajeve, a ne tuženikovu metodu organiziranja i poduzimanja ovog štrajka (primjenom prisile na zaposlenike) te nema razloga za njegovu zabranu u smislu odredbe čl. 215. ZR-a. ${ }^{143}$

\subsubsection{SOCIJALNA ADEKVATNOST ŠTRAJKA - OGRANIČENJE PRAVA NA ŠTRAJK}

Pozitivno pravo na štrajk ne znači da je isto zajamčeno bez ograničenja. Naime, slobode i prava drugih osoba moraju se poštovati. Tako u djelatnostima u kojima bi organiziranje i provedba štrajka mogle ugroziti život, zdravlje i sigurnost građana država je ovlaštena donijeti posebne zakone (lex specialis) kojima se pravo na štrajk u određenoj djelatnosti ograničava. ${ }^{144}$ No, s obzirom na to da je radnicima u takvim djelatnostima oduzeto najvažnije sredstvo u obrani njihovih interesa, potrebno je predvidjeti prikladna jamstva kojima bi se kompenziralo navedeno ograničenje. Najoptimalnije bi bilo predvidjeti u nacionalnim zakonodavstvima adekvatnu, nepristranu i efikasnu koncilijaciju ili arbitražni postupak kojima bi stranke mogle pristupiti u bilo kojoj fazi njihovih kolektivnih pregovora, a čije bi se odluke u potpunosti i promptno izvršavale. ${ }^{145}$ No, za radnike u djelatnostima u kojima je, osim prava na štrajk, oduzeto i pravo na udruživanje, a time i kolektivno pregovaranje, trebalo bi predvidjeti godišnju isplatu određene novčane naknade kao dodatka za vojnu službu, čija je visina u ovisnosti o činu, godinama staža u vojsci te s obzirom na otežane uvjete rada. Kako je istaknuto, već Ustavom Republike Hrvatske ostavljena je mogućnost posebnog pravnog uređenja (ograničenja) prava na štrajk u oružanim snagama, redarstvu, državnoj upravi i javnim službama. U tom smislu i ZR ${ }^{146}$ propisuje da se štrajk u oružanim snagama, policiji, državnoj upravi ${ }^{147}$ i javnim službama uređuje posebnim zakonom. Kod uspostavljenog posebnog pravnog uređenja, opća regulativa ZR-a primjenjuje se tek supsidijarno, tj. ako nije s tim posebnim pravnim uređenjem u suprotnosti.

143 VSRH broj: P-2/98 od 15. rujna 1998.

144 U Francuskoj je posebnim zakonima ograničeno pravo na štrajk: u interventnoj policiji (Zakon od 27. prosinca 1947.); policiji (Zakon od 28. rujna 1948.); zatvorskim stražarima (Dekret od 5. kolovoza 1958.); sucima (Dekret od 22. prosinca 1958.); vojnom osoblju (Zakon od 13. lipnja 1972.); i nekim kategorijama zaposlenika u zračnom prometu (Zakon od 31. prosinca 1984.); radijskom i televizijskom osoblju (Zakon od 29. srpnja 1982.). U Njemačkoj je sukladno čl. 33 st. 5. Ustava zabranjen štrajk svim državnim službenicima, neovisno o području njihove djelatnosti, i proizlazi iz njihova pravnog statusa (Presuda Federalnog administrativnog suda od 27. veljače 2014. - 2 C 1.13). U Italiji je posebnim zakonima ograničeno pravo na štrajk u vojsci (Zakon od 11. srpnja 1978. br. 382., čl. 8.); državnim policijskim snagama (Zakon od 1. travnja 1981., br. 121., čl. 84.; zatvorskim policijskim službenicima (Zakon od 15. prosinca 1990., br. 395., čl. 19., para. 13.); radnicima u nužnim javnim službama (one koje osiguravaju ustavom zajamčena prava građana: na život, zdravlje, sigurnost i slobodu, slobodu kretanja, socijalnu zaštitu i socijalnu sigurnost, obrazovanje i slobodu komunikacija) prema Zakonu br. 146/1990, čl. 1. štrajk nije zabranjen, ali se isti mora provoditi prema posebnim pravilima (štrajk se mora najaviti najmanje deset dana prije početka, nužno je odrediti njegovo trajanje te jamstvo održavanja nužnih poslova za vrijeme trajanja štrajka); u Velikoj Britaniji se predviđa zabrana prava na štrajk, ali na neizravan način u vojsci (poticanjem na Disaffection Act 1934.) i za policijske službenike (Police Act 1996., sekc. 91).

145 ILO, Freedom of Association and Collective Bargaing o.c. para. 164; ILO, Freedom of Association, Digest of decisions and principles of the Freedom of Association Committe of the Governing Body of the ILO, 1996., str. 546.-547.

146 Čl. 220. ZR-a.

147 Radnopravni odnos između državnih službenika i države kao poslodavca uređen je Zakonom o državnim službenicima (Narodne novine, broj 92/2005, 140/2005, 142/2006, 77/2007, 107/2007, 27/2008, 34/2011, 49/2011, 150/2016+1, 34/2012, 38/2013, 1/2015, 138/2015 i 61/2017), na koji radni odnos se supsidijarno primjenjuju odredbe ZR-a (čl. 4. st. 2.). Radnopravni odnos službenika i namještenika u lokalnoj i područnoj samoupravi uređuje Zakon o službenicima i namještenicima u lokalnoj $i$ područnoj (regionalnoj) samoupravi (Narodne novine, broj 86/2008 i 61/2011) koji odredbom čl. 30. st. 1. uređuje pravo na sindikalno udruživanje. 
Posebna ograničenja prava na štrajk u oružanim snagama uređuje Zakon o službi u Oružanim snagama Republike Hrvatske. ${ }^{148}$ Djelatnim vojnim osobama nije dopušten štrajk, niti imaju pravo na sindikalno organiziranje. ${ }^{149}$ Službenicima i namještenicima dopušteno je sindikalno organiziranje u skladu s općim propisima o radu, kao i štrajk, osim u izrijekom navedenim okolnostima. ${ }^{150}$ Posebna ograničenja prava na štrajk u policiji uređuje Zakon o policiji. ${ }^{151}$ Policijski službenici imaju pravo na sindikalno organiziranje, ${ }^{152}$ ali im je ograničeno pravo na štrajk. ${ }^{153}$ Posebno su regulirane okolnosti u kojima je policijski službenik dužan za vrijeme sudjelovanja u štrajku primijeniti policijske ovlasti. ${ }^{154}$

Kada je riječ o javnim službama, Zakon o zdravstvenoj zaštiti ${ }^{155}$ sadrži posebne odredbe o štrajku. Prema odredbama ovog Zakona, štrajk u Hrvatskom zavodu za hitnu medicinu, zavodima za hitnu medicinu jedinica područne (regionalne) samouprave i ugovorenim službama hitne medicine zdravstvenih ustanova nije dopušten, dok u ostalim zdravstvenim djelatnostima zdravstvenih ustanova ne smije započeti prije okončanja postupka mirenja prema općim propisima o štrajku. Ministarstvo uz prethodno mišljenje sindikata, u roku od tri dana od najave štrajka određuje prijeko potrebne poslove koji se moraju neprekidno obavljati radi sprječavanja ugrožavanja života ili nastanka invalidnosti bolesnika za sve zdravstvene djelatnosti zdravstvenih ustanova izuzimajući djelatnosti hitne medicine. Ako sindikat ne prihvaća ovu odluku Ministarstva, može podnijeti pritužbu posebnoj arbitraži u roku od 48 sati od primitka odluke. Arbitraža ima pet članova od kojih po dva člana imenuju Ministarstvo i sindikat, a predsjednika arbitraže imenuje predsjednik Vrhovnog suda Republike Hrvatske i mora donijeti odluku po pritužbi sindikata u roku od tri dana od dana zaprimanja pritužbe. Odluka arbitraže je konačna. Ostali postupak u vođenju štrajka odvija se sukladno općim propisima o štrajku. Posebno je uređena obveza radnika koji obavljaju poslove koji se ne mogu prekidati za vrijeme štrajka da za vrijeme štrajka provode naloge koje izdaje Ministarstvo, a onom zdravstvenom radniku koji ne provede nalog Ministarstva prestaje radni odnos. ${ }^{156}$

148 Zakon o službi u Oružanim snagama Republike Hrvatske (Narodne novine, broj 73/2013, 75/2015 i 50/2016 - dalje: ZOS).

149 Čl. 15. st. 1. i 2. ZOS-a.

150 “(...) u ratnom stanju ili u stanju neposredne ugroženosti neovisnosti, jedinstvenosti i opstojnosti Republike, koji je u neposrednoj vezi s mjerama pripravnosti; u neposrednoj vezi s borbenom spremnošću Oružanih snaga te ugroženosti vitalnih funkcije Oružanih snaga (...)", čl. 15. st. 5. i 6. ZOS-a.

151 Zakon o policiji (Narodne novine, broj 34/2011, 130/2012, 89/2014, 151/2014, 33/2015 i 121/2016 - dalje: Zakon o policiji).

152 Čl. 40. st. 1. Zakona o policiji.

153 Pravo na štrajk nemaju u slučaju: ratnog stanja ili neposredne ugroženosti neovisnosti i jedinstvenosti države; oružane pobune, ustanka i drugih oblika nasilnog ugrožavanja ustavnog poretka Republike Hrvatske ili temeljnih sloboda i prava čovjeka i građana; proglašene elementarne nepogode ili izravne opasnosti od njezina nastanka na području dviju ili više županija ili na cijelom području Republike Hrvatske te drugih nepogoda i nesreća koje ometaju normalno odvijanje života i ugrožavaju sigurnost ljudi i imovine.

154 “(...) ako je to potrebno radi: zaštite života i sigurnosti ljudi; uhićenja i privođenja nadležnom tijelu osobe zatečene u kaznenom djelu za koje se progoni po službenoj dužnosti te sprječavanja počinjenja i otkrivanja počinitelja kaznenog djela za koje se progoni po službenoj dužnosti (...)", čl. 39. Zakona o policiji.

155 Zakon o zdravstvenoj zaštiti (Narodne novine, broj 150/2008, 71/2010, 139/2010, 22/2011, 84/2011, 154/2011, 12/2012, 35/2012, 70/2012, 144/2012, 82/2013, 159/2013 i 22/2014 - dalje: Zakon o zdravstvenoj zaštiti). 


\section{PRAVNE POSLJEDICE SUDJELOVANJA U ŠTRAJKU}

\subsection{PRAVNE POSLJEDICE ZAKONITO ORGANIZIRANOG ŠTRAJKA}

Posljedice sudjelovanja radnika u zakonitom štrajku ovisit će o tome je li u odnosnom pravnom sustavu priznata samo sloboda štrajka ili/i pravo na štrajk. Razlika između ove dvije forme pravnog jamstva u području pravnog uređenja štrajka nije zanemariva, budući da pravo na štrajk pruža snažniju zaštitu za njegove sudionike od same slobode štrajka. Naime, ako je u pravnom sustavu predviđeno pravo na štrajk, to bi za njegove sudionike, ako je isti organiziran i proveden na zakonit način, značilo samo suspenziju ugovora o radu, jer ovakav prekid rada od strana radnika ne bi predstavljao kršenje obveza iz individualnog radnog odnosa. ${ }^{157},{ }^{158}$ Radnik ne smije ni na koji način biti prisiljen sudjelovati u štrajku. Organiziranje zakonitog štrajka, kao i sudjelovanje u provedbi takvog štrajka, ne proizvodi bilo kakve negativne pravne posljedice, kako za sindikat koji je štrajk organizirao, ${ }^{159}$ tako i za radnike ${ }^{160}$ koji su sudjelovali u njegovoj provedbi. Radniku se zbog organiziranja ili sudjelovanja u takvom štrajku ne može otkazati ugovor o radu, niti smije biti stavljen u nepovoljniji položaj od drugih radnika. Poslodavac ne bi smio radnicima zbog nesudjelovanja u štrajku isplatiti veću plaću, jer bi time sudionici štrajka bili stavljeni u nepovoljniji položaj u odnosu na ostale radnike. ${ }^{161}$ Međutim, radnik odgovara (i može mu se zbog tog otkazati ugovor o radu) ako je za vrijeme štrajka počinio neku drugu tešku povredu obveza iz radnog odnosa, ali u ovom slučaju nije riječ o otkazu zbog štrajka. ${ }^{162}$ Naime, iako za vrijeme štrajka miruju temeljna prava i obveze iz radnog odnosa (rad i isplata plaće i dodataka na plaću), radni odnos i dalje traje, pa su radnici koji sudjeluju u štrajku, kao i njihov poslodavac, dužni poštovati ostala prava i obveze koja proizlaze iz tog pravnog odnosa, pa tako i obvezu radnika na savjestan i pošten odnos prema poslodavcu. ${ }^{163}$

Dopušteno je radniku koji je sudjelovao u štrajku umanjiti plaću i dodatke na plaću razmjerno vremenu sudjelovanja u štrajku (vrijeme u kojem radnik nije radio - rad je bio obustav-

157 Primjerice, u Njemačkoj Federalni sud za radne sporove 1955. godine uvodi suspenziju ugovora o radu za radnike koji su sudjelovali u zakonitom štrajku, time transformirajući slobodu štrajka u pravo na štrajk.

158 Čl. 215. st. 1., 2. i 4 . ZR-a.

159 No, u Velikoj Britaniji ne postoji pravo na štrajk, nego samo sloboda štrajka te stoga, u skladu sa striktnim anglosaksonskim pravom, sindikat pozivajući radnika na prestanak rada prima facie krši građansko ili privatno pravo. Međutim, ovakav striktan stav ublažen je donošenjem serije zakonskih odredbi sa svrhom da se sindikatima ipak omogući provedba štrajka priskrbljujući im imunitet protiv mogućih građanskih tužbi, ali samo ako ispune zakonom predviđene uvjete za provedbu štrajka te ograničavajući iznos naknade štete koja se od sindikata može potraživati.

160 Sudjelovanje radnika u štrajku nema za posljedicu raskidno djelovanje ugovora o radu. (Francuska, Code de travail, čl. 521.-1.; Njemačka (Federalni sud za radne sporove, presuda od 28. siječnja 1955. - GS 1/54).

161 Mišljenje Ministarstva rada i socijalne skrbi Republike Hrvatske, Klasa: 110-01/02-01/36, Ur. broj: 524-04/2-02 od 18. ožujka 2002.

162 Čl. 215. st. 3. ZR-a. U francuskoj sudskoj praksi pod ponašanje radnika koje može predstavljati osnovu za izvanredni otkaz ugovora o radu, a koje se dogodilo za vrijeme trajanja štrajka, može se izdvojiti čin nasilja, uništavanje imovine poslodavca, zlouporaba prava na štrajk te prijetnja (Presuda Vrhovnog administrativnog suda od 31. svibnja 1950.).

163 Vidjeti slično: Crnić, I.; Dika, M.; Eraković, A.; Gotovac, V.; Gović, I.; Grgurev, I.: Horvatić, L.; Jelčić, V.; Marinković Drača, D.; Potočnjak, Ž.; Rožman, K.; Ruždjak, M.; Šokčević, S.; Šplajt, Lj.; Tadić, I.; Vukorepa, I.; Zuber, M., Radni odnosi u Republici Hrvatskoj, Pravni fakultet u Zagrebu, Organizator, d.d. Zagreb, Zagreb, 2007., str. 742. 
ljen - mirovala su temeljna prava i obveze iz radnog odnosa). ${ }^{164}$ Navedeno zakonsko određenje dispozitivne je naravi, pa poslodavac i sindikat mogu ugovoriti i povoljniji status radnika. ${ }^{165}$

Budući da se za vrijeme trajanja štrajka poslodavac suočava s povećanim obimom posla, ovlašten je angažirati samo radnike koji nisu kod njega u štrajku za prekovremeni rad u granicama određenim zakonom. No, poslodavac nije ovlašten zapošljavati nove radnike na određeno vrijeme posredstvom agencije za privremeno zapošljavanje ${ }^{166}$ radi zamjene radnika koji su $\mathrm{u}$ štrajku, ${ }^{167}$ ali ne postoje zakonske zapreke za angažiranjem radnika s osnova standardnog instituta ugovora o radu na određeno vrijeme. Stoga se postavlja opravdanost odredbe o zabrani angažiranja agencijskih radnika za zamjenu radnika koji su u štrajku.

\subsection{PRAVNE POSLJEDICE NEZAKONITO ORGANIZIRANOG ŠTRAJKA}

Za razliku od štrajka koji je organiziran u skladu s odredbama zakona, kolektivnog ugovora i pravilima sindikata, nezakonito organiziran štrajk predstavlja protupravnu radnju i poslodavac je ovlašten zahtijevati od sindikata naknadu štete ${ }^{168}$ koju trpi u uzročnoposljedičnoj vezi s nezakonitim štrajkom. Radniku koji je sudjelovao u nezakonitom štrajku može prestati radni odnos, ${ }^{169}$ čak

164 Čl. 217. ZR-a; U Njemačkoj presuda Federalnog suda za radne sporove od 22. ožujka 1994. - 1AZR 622/93.; u Italiji participiranje u štrajku predmnijeva primjenu načela pro rata temporis glede ostvarenja prava na plaću (Presuda Kasacijskog suda br. 7196 od 25. svibnja 2001.) i godišnji odmor (presuda Kasacijskog suda br. 418 od 26. siječnja 1985.) u Nizozemskoj radnicima može biti oduzeta cijela ili dio plaće, kao i socijalna davanja (klauzula 7:627 Građanskog zakonika i klauzula 19.1 Zakona o nezaposlenosti).

165 Vidjeti pravna shvaćanja sudske prakse zauzeta u odlukama: VSRH broj: Revr - 227/09 od 28. travnja 2009., Upravni sud broj: Zpa - 6/2016 od 15. ožujka 2006.

166 U Republici Hrvatskoj, Zakon o radu, čl. 25. st. 4. t. 1.

167 U Francuskoj Code de travail, čl. 124-2-3 i L 122-3.

168 U Njemačkoj Federalni sud za radne sporove u presudi od 27. lipnja 1989. - 1AZR 404/88; u Italiji ugovorna odgovornost sindikata, glede zahtjeva za kompenzacijom zbog organiziranja nezakonitog štrajka dolazi u obzir samo u situaciji kršenja industrijske klauzule mira ugovorene kolektivnim ugovorom, no u nužnim javnim djelatnostima sindikatima se može ustegnuti naknada za plaćeni dopust u svrhe sindikalnih aktivnosti za vrijeme trajanja štrajka, kao i isključenje sindikata iz kolektivnih pregovora u kojima sudjeluju. Organizatori, odnosno vođe nezakonitog štrajka mogu biti prema čl. 330. Kaznenog zakonika kazneno sankcionirani, iako je Ustavni talijanski sud ovakvo postupanje proglasio protuustavnim (presuda Ustavnog suda br. 31/1969); u Nizozemskoj poslodavac ili treća strana u slučaju nastavka nezakonitog štrajka po donošenju presude o njegovoj nezakonitosti mogu tražiti naknadu štete (Jacobs, A. J. T. M., Collectief Arbeidsrecht, Kluwer, Deventer, 2013., str. 230.); u Sloveniji sindikat neće biti odgovoran za štetu zbog samog čina organiziranja i provedbe štrajka, već ako se uz to ispune i uvjeti predviđeni obligacijskim pravom (presuda Vrhovnog suda od 20. lipnja 2003., RS VIII Ips. 48/2003; u Velikoj Britaniji poslodavac zbog organiziranja nezakonitog štrajka može tražiti od sindikata naknadu štete (Deakin, S.; Johnston, A.; Markesinis, B., Tort Law, Oxford, 2012., str. 792.), No, zbog uvedenih ograničenja glede visine iznosa štete (Trade Union and Labour Relations Act 1992., str. 22. - tablica) te dužine sudskog postupka i činjenice da isti neće rezultirati dobrim industrijskim odnosima (Deakin, S., Morris, G., Hart, 2012., str. 1090.), poslodavci se u sudskom postupku umjesto na zahtjev za naknadom štete više orijentiraju na sudsku zabranu daljnje provedbe nezakonitog štrajka; u Njemačkoj poslodavac može tražiti naknadu štete ili na temelju odštetnog prava ili na temelju kršenja industrijske klauzule mira. Budući da se u tom slučaju traži nehat na strani sindikata, sporno je pitanje standarda kojeg se sindikati pri organiziranju štrajka moraju pridržavati. No, sudska praksa drži da sindikat neće biti odgovoran za štetu u slučaju sudskog proglašenja štrajka nezakonitim, ako je pri organiziranju štrajka opravdano smatrao da bi u eventualnom sudskom postupku glede utvrđivanja zakonitosti štrajka, sud isti proglasio zakonitim (presuda Federalnog suda za radne sporove od 21. ožujka 1978. - AZR 11/76; presuda od 10. prosinca 2002. - AZR 96702 te od 19. lipnja 2012. - AZR 775/10).

169 U Nizozemskoj čak i radnici koji sudjeluju u nezakonitom štrajku pravno su zaštićeni sve do okončanja štrajka po sudskom proglašenju nezakonitosti istog (presuda Vrhovnog suda od 22. travnja 1988. NJ 1988. 952). Otkaz kao sankcija je moguć, ali se u odluci valja rukovoditi testom proporcionalnosti; u Njemačkoj radnik koji je sudjelovao u nezakonitom štrajku može dobiti redoviti, pa čak i izvanredni otkaz. Utemeljenost otkaza, kao i njegov vid ovisit će o tome je li nezakonitost štrajka manje ili više uočljiva (presuda Federalnog suda za radne sporove od 29. studenog 1983. - 1AZR 469/82), kao i odnosu radnika spram takvog štrajka. Naime, ako je radnik sudjelovao u štrajku samo iz čina solidarnosti i pri tom imao odvojen odnos prema štrajku to će za 
i izvanrednim otkazom ugovora o radu. ${ }^{170}$ Štoviše, prema shvaćanju sudske prakse, sama činjenica da radnik nije znao da sudjeluje u nezakonitom štrajku ne predstavlja za tog radnika olakotnu okolnost glede procjene opravdanosti otkaza. No, poslodavcu kod kojeg je u tijeku nezakoniti štrajk prvenstveno je u interesu tražiti sudsku zabranu nezakonitog štrajka.

\section{POSTUPAK SUDSKE ZABRANE NEZAKONITOG ŠTRAJKA}

U okolnostima kada poslodavac, odnosno udruga poslodavaca (ovisno o činjenici tko je pasivni subjekt štrajka) ocijene da nisu ispunjene sve navedene materijalne i postupovne pretpostavke zakonitog štrajka, ovlašteni su od nadležnog suda ${ }^{171}$ u parničnom postupku zahtijevati zabranu organiziranja i poduzimanja tog štrajka.

\subsection{AKTIVNO I PASIVNO LEGITIMIRANE OSOBE U POSTUPKU}

Poslodavac, odnosno udruga poslodavaca protiv koje je štrajk usmjeren, aktivno su legitimirani od nadležnog suda zahtijevati zabranu organiziranja i poduzimanja štrajka za kojeg cijene da je nezakonit. ${ }^{172}$ To je ovlast svakog poslodavca kod kojeg se štrajk organizira i bez obzira na činjenicu je li primarno na tog poslodavca štrajk i usmjeren (kod štrajka solidarnosti). Udruga poslodavaca zabranu štrajka može zahtijevati u okolnostima kada je riječ o kolektivnom radnom sporu u kojem ta udruga sudjeluje (npr. štrajk u slučaju spora o sklapanju granskog kolektivnog ugovora s tom udrugom), ali takvu legitimaciju nema kada se štrajk organizira i usmjeren je samo protiv jednog poslodavca koji je član te udruge.

Zahtjev treba biti usmjeren (pasivno legitimirane osobe) protiv sindikata koji štrajk organizira. Međutim, nezakonit štrajk mogu organizirati i radničko vijeće ili skupina radnika, pa se pasivna legitimacija zahtjeva zabrane organiziranja i poduzimanja štrajka u ovim okolnostima usmjerava prema tim subjektima. ${ }^{173}$

njega predstavljati olakotnu okolnost; u Italiji radnik koji je sudjelovao u nezakonitom štrajku podliježe disciplinskoj (novčana kazna ili suspenzija s rada) i građanskoj odgovornosti (presuda Kasacijskog suda od 28. ožujka 1986., br. 2214), no ovakvo ponašanje radnika ne može biti osnova za prestanak radnog odnosa, osim za radnike u nužnim državnim djelatnostima (Zakon br. 146/1990).

170 Vidjeti pravna shvaćanja sudske prakse zauzeta u odlukama: Ustavni sud RH broj: U-III-1831/2006 od 24. ožujka 2009., VSRH broj: Gž-1/98 od 17. veljače 1998., Revr-586/03 od 14. veljače 2004., Revr-175/02 od 12. lipnja 2002., Rev-417/99 od 4. travnja 2001., Revr-482/05 od 25. listopada 2005., Revr-583/03 od 20. siječnja 2004. i Gž-1/98 od 17. veljače 1998.

171 U Nizozemskoj se zakonitost štrajka procjenjuje u izvanrednom (skraćenom) postupku koji je brz, relativno jeftin i autoritativan. Sindikati odmah prestaju sa štrajkom po donošenju presude o nezakonitosti štrajka, i vrlo rijetko na odluku Suda ulažu prigovor (Jacobs, A. T. J. M., op. cit. u bilj. 168, str. 172.); u Velikoj Britaniji nepoštovanje sudske zabrane nezakonitog štrajka ima za posljedicu kaznene sankcije, čak i u vidu zatvorske kazne, iako se u stvarnosti zaista rijetko primjenjuje (Deakin, S., Morris, G., op. cit. u bilj. 168, str. 1097.).

173 Vidjeti pravna shvaćanja sudske prakse zauzeta u odlukama: VSRH broj: Gž-42/99 od 10. svibnja 2000. i Gž-15/99 od 16. lipnja 1999. 


\subsection{NADLEŽNOST SUDA I ROKOVI U KOJIMA SUD MORA ODLUČITI}

Nadležnost suda se utvrđuje s obzirom na teritorijalni obuhvat štrajka. Ako štrajk obuhvaća područje samo jedne županije o zabrani štrajka u prvom stupnju odlučuje nadležni županijski sud u vijeću sastavljenom od tri suca, ${ }^{174}$ a ako štrajk obuhvaća područje dviju ili više županija, o zabrani štrajka u prvom stupnju u istom sastavu odlučuje (kao zakonom generalno delegirani) Županijski sud u Zagrebu. ${ }^{175}$ Odluka o zahtjevu u prvom stupnju mora se donijeti u roku od četiri dana od dana podnošenja zahtjeva. ${ }^{176} \mathrm{O}$ žalbi protiv odluke suda prvog stupnja odlučuje Vrhovni sud Republike Hrvatske u roku od pet dana od dana dostave prvostupanjskog predmeta. ${ }^{177}$

Kratki rokovi u kojima sudovi moraju odlučiti uvjetovani su okolnošću da nezakonit štrajk i u manjem vremenskom trajanju poslodavcu može prouzročiti veliku štetu. Međutim, riječ je o instruktivnim rokovima, pa produljenjem postupka sudovi ne čine bitnu postupovnu povredu. ${ }^{178}, 179$

\subsection{ZAHTJEV I ODLUKA SUDA O ZAHTJEVU}

Tužbeni zahtjev za zabranu i organiziranje štrajka može se podnijeti od najave štrajka (npr. već iz najave je vidljivo da štrajk ne organizira ovlaštena osoba ili da štrajk nema dopuštenu svrhu), tijekom njegova trajanja (npr. štrajk se provodi nezakonito), pa sve do okončanja štrajka. ${ }^{180}$ Nakon provedenog postupka sud, ako utvrdi da štrajk prema nekom od materijalnopravnih ili postupovnopravnih elemenata nije zakonit, donosi odluku (presudu) kojom prihvaća zahtjev tužitelja postavljen na zabranu organiziranja i poduzimanja štrajka. U protivnom donosi odluku kojom se zahtjev tužitelja odbija kao neosnovan. Međutim, ako je štrajk s trenutkom zaključenja glavne rasprave okončan, sud će odbiti zahtjev tužitelja jer sud odlučuje na temelju činjeničnog stanja utvrđenog s trenutkom zaključenja glavne rasprave. Pritom je, prema pravnom shvaćanju kojeg su sudovi zauzeli, za prestanak štrajka nužno da je isti faktično prestao te pritom nije potrebna formalna odluka. ${ }^{181} \mathrm{U}$ navedenim okolnostima poslodavac osnovano može postaviti zahtjev na utvrđenje da je štrajk nezakonit, a koje utvrđenje ujedno predstavlja prethodno pitanje kod zahtjeva poslodavca za naknadu štete koju trpi u uzročnoposljedičnoj vezi s nezakonito organiziranim i provedenim štrajkom. ${ }^{182} \mathrm{U}$ sporu radi zabrane štrajka sud

174 Čl. 219. st. 1. ZR-a.

175 C̆l. 219. st. 2. ZR-a.

176 Čl. 219. st. 4. ZR-a.

177 Čl. 219. st. 3. i 5. ZR-a.

178 Tako VSRH broj: Rev-459/97 od 11. travnja 1997.

179 Vidjeti pravna shvaćanja sudske prakse zauzeta u odlukama: VSRH broj: Gž-14/14 od 27. svibnja 2014., Gž-1/97 od 8. siječnja 1997. i Grl-25/04 od 21. siječnja 2004.

180 Tako i sudska praksa prema shvaćanju zauzetom u predmetu VSRH broj: Gž-15/13 od 11. lipnja 2013.

181 VSRH broj Gž-1/03 od 28. veljača 2003.

182 Tako VSRH u odlukama: Gž-42/99 od 10. svibnja 2000., VSRH broj: Gž-25/99 od 11. kolovoza 1999., te Gž-11/00 od 2. ožujka 2000. 
može odrediti privremene mjere koje se primjenjuju u ovršnom postupku radi sprječavanja nasilnog postupanja ili radi otklanjanja nenadoknadive štete. ${ }^{183},{ }^{184}$

\section{ZAKLJUČNA RAZMATRANJA}

Budući da smo rješenja de lege ferenda predložili tijekom analize materijalnih i procesnih pretpostavki zakonitosti štrajka u daljnjem tekstu iznosimo neka zaključna razmatranja. Naime, komparativnom analizom nekoliko pravnih sustava zaključili smo da je značenje pojma štrajk više no nejasno, bilo zbog izostanka, odnosno nedovoljno precizne definicije, bilo zbog različitosti određenja u različitim pravnim sustavima. Situaciju usložnjava i činjenica da o značenju navedenog pojma postoji kontroverza i u radnopravnoj doktrini. No, izložena situacija predstavlja samo jedan od čimbenika koji utječu na problem određivanja granica dopuštenosti (zakonitosti) štrajka. Ovom se mogu pridodati i različita rješenja glede tumačenja pojma slobode udruživanja, koja je gotovo u svim pravnim sustavima priznata kao temeljno ljudsko pravo, a koja može, ali i ne mora činiti pravnu osnovu prava na štrajk. No, kod restriktivnog tumačenja kojem su skloni neki pravni sustavi, pravo na štrajk ne čini sastavni dio ovog prava, što onda utječe i na negativnu procjenu njegove zakonitosti. Nadalje je nejasno je li pravo na štrajk priznato samo kao sloboda ili kao i sloboda i pravo? U ovisnosti o odgovoru na ovo pitanje ovisi i učinak štrajka na individualni radni odnos radnika koji je sudjelovao u zakonitom štrajku. Određenje aktivnog subjekta štrajka ovisi o tome je li pravo na štrajk individualno, kolektivno ili dvostruko fundamentalno pravo. Različitost pravnih sustava u sferi uređenja prava na štrajk ogleda se i u obimu materijalnih i procesnih pretpostavki njegove zakonitosti detaljno obrađenih u ovom radu. U prethodnim razmatranjima vidjeli smo da je, u situaciji podnormiranosti, odnosno nejasno postavljenih ustavnih i zakonskih normi, odgovore na postavljena pitanja dala sudska praksa (nacionalnih sudova, Suda pravde Europske unije te Suda za ljudska prava Vijeća Europe). I ponovno svjedočimo različitim rješenjima. No, svatko tko se bavi komparativnim pravom, odnosno pravom općenito, trebao bi znati da postoji izvjesni rascjep između pravne regulative i stanja "na terenu". Naime, vrlo često se štrajkovi poduzimaju izvan, odnosno mimo onog što je normirano, budući da je gotovo nemoguće predvidjeti sve okolnosti s kojima se sudionici mogu suočiti tijekom štrajka, a s druge strane prenormiranost može odvesti na sklizak teren u smislu ograničavanja odnosno otežanog ostvarivanja prava na štrajk čime bi se doveo u pitanje štrajk kao najpogodnije sredstvo uspostave ravnoteže pregovaračkih snaga između radnika i poslodavca na tržištu rada. Primjerice, pitanja o kojima se dodatno može raspravljati su, među ostalima, sindikalna demokracija, disciplina štrajkaša, osjećaj odgovornosti aktivnih i pasivnih subjekata štrajka u pogledu poštovanja prava i sloboda suprotne strane, ovisnost odnosno neovisnost sindikata, broj i struktura sudionika štrajka, nametanje obligatorne arbitraže, kaznene sankcije za sudjelovanje u nezakonitom štrajku, nepriznavanje prava na štrajk u javnim djelatnostima i tome sl.

183 VSRH broj: Gž-30/13 od 4. prosinca 2013.

184 Vidjeti pravna shvaćanja sudske prakse zauzeta u odlukama: VSRH broj: Gž-6/99 od 8. travnja 1999., Gž-1/97 od 8. siječnja 1997., Gž-12/98 od 30. lipnja 1998., Gž-6/98 od 22. travnja 1998., Gž-5/96 od 22. lipnja 1996., Gž-42/99 od 10. svibnja 2000., Gž-3/97 od 17. travnja 1997., Gž-9/97 od 8. siječnja 1998. i Gž-18/14 od 17. srpnja 2014. 
Zaključno, u doba prisutne globalizacije ekonomije koja nužno utječe i na radne odnose u smislu još većeg poremećaja navedene ravnoteže u korist svijeta kapitala, dolazi do transformacije tradicionalne zaštite radnog mjesta prema zaštiti zaposlenja (iako se ista čini podrednom ostvarenju ekonomskih ciljeva poslodavca) gdje se rizik troška rada premješta s poslodavca na radnika. ${ }^{185}$ Iako se politikom fleksigurnosti, ${ }^{186}$ koju snažno promovira Europska komisija, nastoji ublažiti novonastala neravnoteža koja se zalaže da i radno pravo EU-a i nacionalna radna zakonodavstva težište više stave na socijalni aspekt "socijalno-tržišne ekonomije", u kontekstu fleksibilnosti u radnim odnosima više je no razvidna erozija radničkih prava. No, u eri drastičnog opadanja sindikalnog članstva postavlja se pitanje efikasne borbe za unaprjeđenje ekonomskih i socijalnih interesa radnika, bilo kroz produktivan socijalni dijalog, bilo kroz štrajk. Nadamo se da se svijet rada, posebice u današnjim okolnostima, neće tako lako odreći prava za čije je priznanje mukotrpno stoljećima krčio put.

\section{LITERATURA}

1. Adlercreutz, A., Sweden. International Encyclopedia for Labour Law and Industrial Relations, Deventer, Kluwer, god. 9, 1982.

2. Bilić, A., Fleksibilnost i deregulacija u radnopravnim odnosima, doktorska disertacija, Pravni fakultet Sveučilišta u Splitu, Split, 2012.

3. Bilić, A., Transformacija radnopravnog odnosa, Zbornik Pravnog fakulteta Sveučilišta u Rijeci, god. 32, br. 2, 2011.

4. Birk, R., Industrial conflict: The Law of Strikes and Lock-outs, Comparative Labour Law and Industrial Relations, Deventer, Kluwer Law and Taxation Publishers, 1985.

5. Bodiroga-Vukobrat, N., Barić, S., Povelja temeljnih ljudskih prava Europske unije s komentarom, Organizator, Zagreb, 2002.

6. Buklijaš, B., Kolektivno radno pravo, Pravni fakultet Sveučilišta u Splitu, Split, 2012,

7. Buklijaš, B., Bilić, A., Međunarodno radno pravo, Pravni fakultet Sveučilišta u Splitu, Split, 2006.

8. Burger, F., The Right to Strike: Austria, u: Waas, B., (ed.) The Right to Strike, A Comparative View, Wolters Kluwer Law and Business, 2014.

9. Carta, L.; Dechamps, M.; Janin, A.; Le Luduec, a. L., France, u: The right to strike. A comparative perspective. A study of national law in six EU states, The institute of employment rights, 2009.

10. Deakin, S.; Johnston, A.; Markesinis, B., Tort Law, Oxford, 2012.

11. Ewing, K. D., Hendy, J., The dramatic implications of Demir and Baykara, Industrial Law Journal, god. 39, br. 1, 2010.

12. Frntić, D. F.; Gović Penić, I.; Hanzalek, D.; Milković, D.; Novaković, N.; Rožman, K., Detaljni komentar Zakona o radu, Radno pravo, Zagreb, 2016.

185 Detaljnije: Bilić, A., Transformacija radnopravnog odnosa, Zbornik Pravnog fakulteta Sveučilišta u Rijeci, god. 32. br. 2, 2011., str. 755.-792.

186 O kritici rješenja politike fleksigurnosti detaljnije: Bilić, A., Flexicurity: Way Out or Way With Traps and Hurdles?, Economic and Social Development, 22 International Scientific Conference on Economic and Social Development - "The Legal Challenges of Modern World", Split, 2017., str. 24.-36., dostupno na: http://www.esd-conference.com/past-conferences, pristupljeno 16. studenog 2017.; Bilić, A., Perkušić, T., Croatian Labour Market Development Perspectives in the Context of Flexicurity, Economic and Social Development, 22 International Scientific Conference on Economic and Social Development - "The Legal Challenges of Modern World", Split, 2017., str. 434.-447., dostupno na: http://www.esd-conference.com/past-conferences, pristupljeno 16. studenog 2017. 
13. Gorman, R. A., Basic Text on Labor Law, Unionisation and Collective Bargaining, St. Paul, Minnesota, West Publishing Company, 1976.

14. Gović, I.; Marinković Drača, D.; Milković, D., Zakon o radu - komentar, sudska praksa, ogledni primjeri, TIB - poslovno savjetovanje d.o.o. Zagreb, Zagreb, 2010.

15. Herman, V., Pravo na štrajk u državama članicama Europske unije, Pravni vjesnik, god. 19, br. 1-2, 2003.

16. Houwerzijl, M., Roozendaal, W., The Right to Strike: Netherlands, u: Waas, B., (ed.) The Right to Strike, A Comparative View, Wolters Kluwer Law and Business, 2014.

17. Jacobs, A. J. T. M., Traité de droit du travail, L. G. D. J. Paris, 1986.

18. Kahn-Freund, O., The Right to Strike. Its Scope and Limitations, Strasbourg: Council of Europe, 1974.

19. Kessler, F., The Right to Strike: France, u: Waas, B., (ed.) The Right to Strike, A Comparative View , Wolters Kluwer Law and Business, 2014.

20. Končar, P., The Right to Strike: Slovenia, u: Waas, B., (ed.) The Right to Strike, A Comparative View, Wolters Kluwer Law and Business, 2014.

21. Marinković Drača, D., Štrajk - priručnik za sindikate i poslodavce, TIM pres, Zagreb, 2005.

22. Otto, H., Arbeitskampf und Schlichtingsrecht, C.H. Beck, 2006.

23. Pascucci, P., The Right to Strike: Italy, u: Waas, B., (ed.) The Right to Strike, A Comparative View, Wolters Kluwer Law and Business, 2014.

24. Potočnjak, Ž., Pravo na štrajk, Naša zakonitost, br. 7-8, 1989.

25. Potočnjak, Ž., Pravo na štrajk, Pravni fakultet u Zagrebu, Savez samostalnih sindikata Hrvatske, Zagreb, 1992.

26. Rozić, I., Kolektivno radno pravo, JP NIO Službeni list BiH, Sarajevo, 2013.

27. Ruždjak, M., Zakon o radu - komentar, sudska praksa, primjeri ugovora o radu i općih akata, Poslovni zbornik, Zagreb, 2005.

28. Triva, S., Dika, M., Građansko parnično procesno pravo, Narodne novine, Zagreb, 2004.

29. Učur, M. Đ., Smokvina, V., Industrijske akcije kao sindikalna prava i slobode, Zbornik Pravnog fakulteta Sveučilišta u Rijeci (1991.), god. 31, br. 2, 2010.

30. Waas, B., The Right to Strike, A Comparative View, u: Waas, B., (ed.) The Right to Strike, A Comparative View, Wolters Kluwer Law and Business, 2014.

31. Waas, B., The Right to Strike: Germany, u: Waas, B., (ed.) The Right to Strike, A Comparative View, Wolters Kluwer Law and Business, 2014.,

32. Weiss, M., Labour Law and Industrial Relations in the Federal Republic of Germany, Deventer, Kluwer Law and Taxation Publishers, 1987.

\section{POPIS PROPISA, AKATA I SUDSKIH ODLUKA}

1. Charter of Fundamental Rights of EU, OJ C364, od 18. prosinca 2000.

2. Europska konvencija za zaštitu ljudskih prava i temeljnih sloboda i prateći protokoli (Narodne novine, Međunarodni ugovori, broj 18/1997, 6/1999, 8/1999, 14/2002, 13/2003, 9/2005, 1/2006 i $2 / 2010)$.

3. Europska socijalna povelja (Narodne novine, Međunarodni ugovori, broj 15/2002). 
4. ILO, Freedom of Association and Collective Bargaing, General Survey of the reports on the Freedom of association and protection of the Right to organize Convention, 1948., and the Right to organise and Collective Bargaing Convention, 1949, Report III (part 4 B), International Labour Conference, 81 st Session, Geneva, 1994, para 168.

5. ILO, Freedom of Association and Collective Bargaing.o.c. para. 164; ILO, freedom of association: Digest of decisions and principles of the Freedom of Association Committe of the Governing Body of the ILO, 1996.

6. ILO, Freedom of Association: Digest of decisions and principles of the Freedom of Association Committee of the Governing body of the ILO, 1996.

7. Konvencija Međunarodne organizacije rada br. 87. o pravu na sindikalno organiziranje (Narodne novine, međunarodni ugovori, broj 3/2000).

8. Konvencije Međunarodne organizacije rada br. 98. o pravu na organiziranje i slobodno kolektivno pregovaranje (Narodne novine, Međunarodni ugovori, broj 3/2000).

9. Međunarodni pakt o ekonomskim, socijalnim i kulturnim pravima čovjeka (Službeni list SFRJ, broj 7/1971, Narodne novine, Međunarodni ugovori, broj 12/1993.).

10. Mišljenje Ministarstva rada i socijalne skrbi Republike Hrvatske, Klasa: 110-01/02-01/36, Ur. broj: 524-04/2-02 od 18. ožujka 2002.

11. Pravilnik o načinu izbora miritelja i provođenju postupka mirenja u kolektivnim radnim sporovima (Narodne novine, broj 130/2015).

12. Pravno mišljenje Ministarstva rada i socijalne skrbi Republike Hrvatske, Klasa: 110-01/11-01/244, Ur. broj: 526-08-01-01/5-11-2.

13. Stručno mišljenje Ministarstva rada i socijalne skrbi Republike Hrvatske, Klasa: 110-01/03-01/18, Ur. broj: 524-04/2-03-2 od 16. siječnja 2003.

14. Ustavni zakon o Ustavnom sudu Republike Hrvatske (Narodne novine, broj 99/1999, 29/2002 i 49/2002).

15. Zakon o arbitraži (Narodne novine, broj 88/2001).

16. Zakon o državnim službenicima (Narodne novine, broj 92/2005, 140/2005, 142/2006, 77/2007, 107/2007, 27/2008, 34/2011, 49/2011, 150/2016+1, 34/2012, 38/2013, 1/2015, 138/2015 i 61/2017).

17. Zakon o policiji (Narodne novine, broj 34/2011, 130/2012, 89/2014, 151/2041, 33/2015 i 121/2016).

18. Zakon o radu (Narodne novine, broj 149/2009, 61/2011, 82/2012, 73/2013, 93/2014).

19. Zakon o radu (Narodne novine, broj 38/1995, 54/1995, 65/1995, 102/1998, 17/2001, 82/2001, 114/2003, 142/2003, 123/2003, 30/2004, 68/2005, 94/2009, 149/2009).

20. Zakon o radu (Narodne novine, broj 93/2014).

21. Zakon o reprezentativnosti udruga poslodavaca i sindikata (Narodne novine, broj 93/2014 i 26/2015).

22. Zakon o službenicima i namještenicima u lokalnoj i područnoj (regionalnoj) samoupravi (Narodne novine, broj 86/2008 i 61/2011).

23. Zakon o službi u oružanim snagama Republike Hrvatske (Narodne novine, broj 73/2013, 75/2015 i 50/2016).

24. Zakon o zdravstvenoj zaštiti (Narodne novine, broj 150/2008, 71/2010, 139/2010, 22/2011, 84/2011, 154/2011, 12/2012, 35/2012, 70/2012, 144/2012, 82/2013, 159/2013 i 22/2014). 


\section{MREŽNI IZVORI}

1. Bilić, A., Perkušić, T., Croatian labour market development perspectives in the context of flexicurity, Economic and Social Development, 22 International Scientific Conference on Economic and Social Development - "The Legal Challenges of Modern World", Split, 2017., dostupno na: http://www. esd-conference.com/past-conferences, pristupljeno 16. studenog 2017.

2. Bilić, A., Flexicurity: way out or way with traps and hurdles?, Economic and Social Development, 22 International Scientific Conference on Economic and Social Development-, The Legal Challenges of Modern World“, Split, 2017., dostupno na: http://www.esd-conference.com/past-conferences, pristupiljeno 16. studenog 2017.

3. Mišljenje Ministarstva gospodarstva, rada i poduzetništva od 4. srpnja 2011.g. (izvor: http://www. iusinfo.hr/OfficialPosition/Content.aspx?SOPI=MMIN201D20110704N42\&Doc=MMIN-HR, pristupljeno 16. kolovoza 2017.).

4. Pročišćeni tekst EU-a i UFEU-a po stupanju na snagu Lisabonskog ugovora, OJ C83/114 od 30. ožujka 2010., dostupan na: http://old.hnb.hr/medjunarodna-suradnja/dokumenti/h-ugovor-o-eu-funkcioniranju-eu.pdf.

\section{POPIS KRATICA}

MOR = Međunarodna organizacija rada

$\mathrm{RH} \quad=$ Republika Hrvatska

$\mathrm{ZR} \quad=$ Zakon o radu

VSRH = Vrhovni sud Republike Hrvatske

ILO = International Labour Organization (Međunarodna organizacija rada)

GSV $\quad=$ Gospodarsko socijalno vijeće

ZOS = Zakon o službi u oružanim snagama Republike Hrvatske

$\mathrm{EU}=$ Europska unija

UFEU = Ugovor o funkcioniranju Europske unije 
Andrijana Bilić*

Trpimir Perkušić**

\section{LEGITIMACY OF STRIKE - QUI, QUID, QUANDO ET QUOMODO?}

\section{Summary}

An accelerated movement of capital and services in the context of globalisation has been noted outside of the national borders of EU member states. Therefore, both transnational transactions and dispatched workers issues have become daily commonplace. Given that employers wish to take advantage of what the individual internal market has to offer and thus decrease the price of work, these workers find themselves in an unenviable position. In order to protect their economic and social welfare interests, it is necessary to establish a productive transnational social welfare dialogue. Due to various levels of economic development and social welfare protection, collective bargaining of social partners and initiating strike as the most effective industrial relations on the part of the world of work, might fail. However, collective actions are still linked to the national system of industrial relations marked by their specific characteristics. Nevertheless, when it comes to the regulation of industrial actions, it should be emphasised that a whole series of legal loopholes and/or poor solutions exist within these systems, in particular related to the right to strike. The situation is even more complicated by the existence of international and regional legal sources governing this subject and binding the respective countries, particularly when national legislation provisions are not harmonised. Thus, it is easy to conclude that the current situation makes it more difficult, for not only strike organisation and implementation, but also for differentiating a legal from an illegal strike at transnational and national level. The paper applies the comparative method for bringing out numerous criticisms de lege lata while offering solutions de lege ferenda.

Keywords: $\quad$ Legal and illegal strike, substantive and procedural presumptions of the legality of strike action, court injunction against strike action

\section{(c) (1) (\$)}

This work is licensed under a Creative Commons

Attribution-NonCommercial 4.0 International License.

* Andrijana Bilić, PhD, Assistant Professor, Department of Labour and Social Welfare Law, Faculty of Law, University of Split, Domovinskog rata 8, 21000 Split. Republic of Croatia. Email address: andrijana.bilic@pravst.hr. ORCID: https://orcid.org/00000002-1272-4749.

** Trpimir Perkušić, LLM, Teaching Assistant, Department of Labour and Social Welfare Law, Faculty of Law, University of Split. Domovinskog rata 8, 21000 Split, Republic of Croatia. Email address: trpimir.perkusic@pravst.hr. ORCID: https://orcid. org/0000-0003-4561-9926. 